Portland State University

PDXScholar

$5-1-1970$

\title{
The great debate : an examination of conflicting views regarding American defense policies, 1950-1951
}

Glen J. Jackson

Portland State University

Follow this and additional works at: https://pdxscholar.library.pdx.edu/open_access_etds Let us know how access to this document benefits you.

\section{Recommended Citation}

Jackson, Glen J., "The great debate : an examination of conflicting views regarding American defense policies, 1950-1951" (1970). Dissertations and Theses. Paper 679.

https://doi.org/10.15760/etd.679

This Thesis is brought to you for free and open access. It has been accepted for inclusion in Dissertations and Theses by an authorized administrator of PDXScholar. Please contact us if we can make this document more accessible: pdxscholar@pdx.edu. 
AN ABSTRACT OF TEE THESIS OF GI on J. R. Jackson for tho Master of Solence in Toaching presented May 22, 1970.

Title: The Great Debate: An Examination of Conflicting Views Regarding American Defense Pol101es, 19501951.

APPROVED BY MEMBERS OF THE THESIS COMMITTEE:

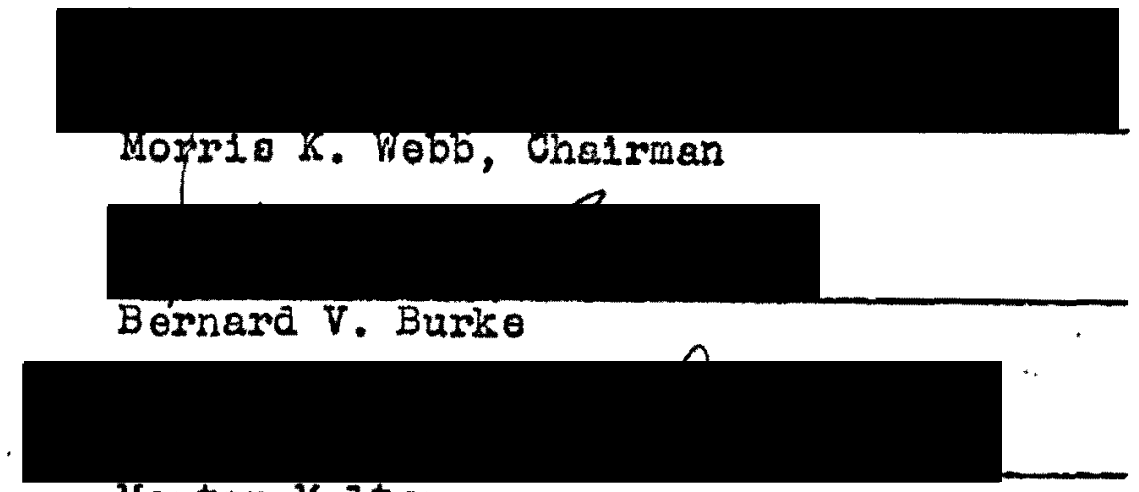

Morton Malter

This paper is an examination of conflicting viewe regarding Amerloan defense polloy which surfaced in a debate during the winter and spring of 1950-51 between the Truman Administration and 1ta supporters and a group of conservat1ve Republicans. The research problen involved unraveling the debate's manifold 18sues, determining its outcome, and analysing the 1mpact of that outcome on the future of American foreign polloy, partioularly in Asia.

The dobate's princlplo 1 seues contered around American defense of Europe versug defonse of Agla and the rellance on ground troops rather than on sea and alr power: Tho 
Adminlstration, while believing the United States should help repel the Communist Invasion of South Korea, also adrocated sending additional troops to Europe. Republican critica disagreed, arguing there was no overt Communist threat in Europe, only in Asia, and American erforts there should be redoubled. Furthermore, they clalmed that whatever defense of Europe was necessary could best be accompilshed through the use of naval and alr power, not the Infantry.

The immediate result of the depate was victory for the Adminlstration. A majority of senators was convinoed that additional American troops were needed in Europe, and the Senate passed a resolution expressing that opinion in eariy April, 1951, ostensibly ending the debate. The victory was short-I1ved, however. The debate had repercussions at the polls in 1952 and holped swoep the Republicans into office. The ultimate outcome of the debate was to bring the conservative arguments to the fore and remold American forelgn policy so that it conformed to those views.

The Information used in this paper was collected from books and contemporary perlodicals, newspapers, and government publications. The only leading conservative crit10 st1Il Ilving, Will1am F. Knowland, did not respond to a letter requesting clarification of statenents he made during tho dobate. The memoirs of President Truman and Dean Acheson, his Secretary of State, recelved special attention. 
Works on and by Senat or Robert A. Taft, the Publis Papers of the Presidents of the United States, The Nev York T1me日 and The Times of London, and The Department of State Bulletin wero partioularly userul. One potentialis 1mportant primary souroe, a paper written by the National Security Counc1l in 1950, remalns claselfled and was thus unavailable. 
THE GREAT DEBATE: AN EXAMINATION OF CONFLICTING VIEWS REGARDING AMERICAN DEFENSE POLICIES, 1950-1952

by

GLEN J.R. JACKSON

A thesis submitted in partial fulfillment or the requirements for the degree of

MASTER OF SCIENCE

in

TEACHING

Portland State University

1970 
- TO THE ORBIOE OF GRADUATE STUDIES:

The members of the Committeo approve the thesis of Glen J. R. Jackson presented May 22, 1970.
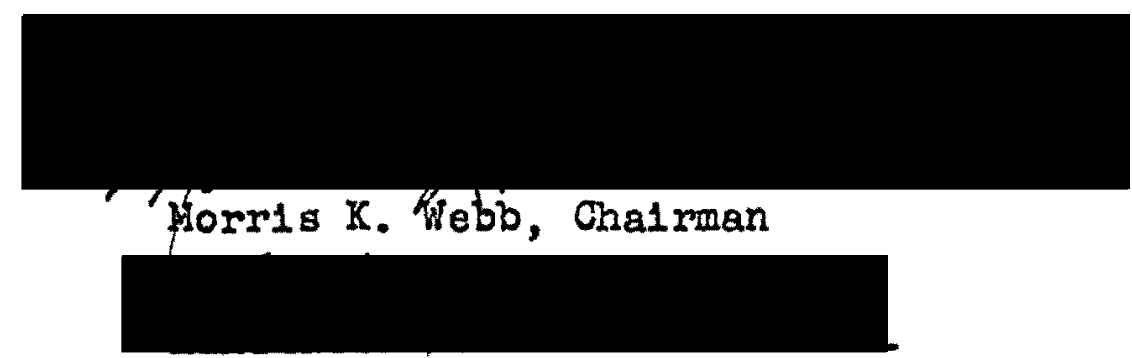

Bernard V. Burke

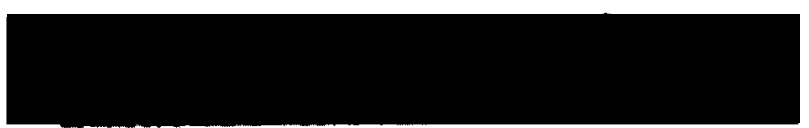

Norton Malter

APPROVED:

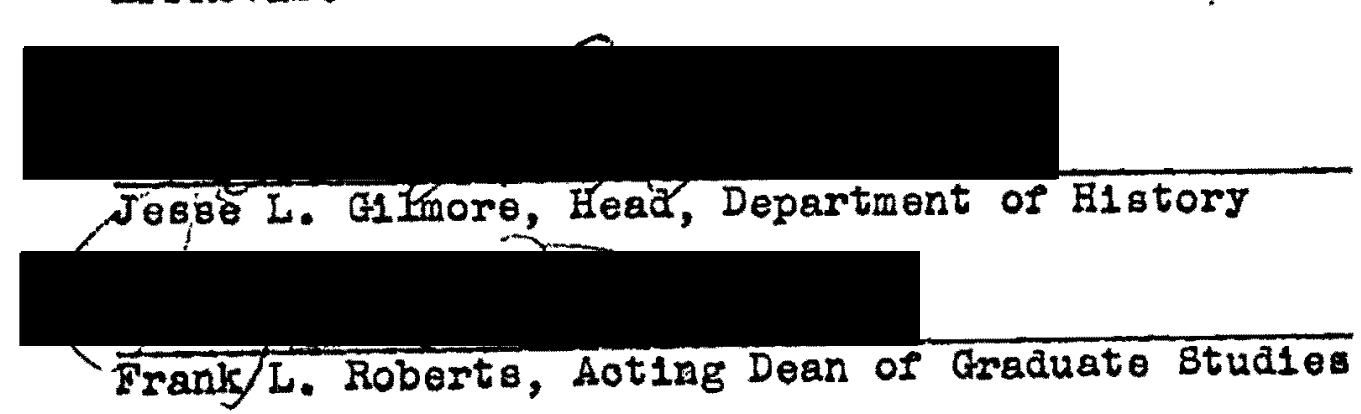




\section{TABLE OF CONTENTS}

CRAPTER

PAGE

I INTRODUCTION ................ I

II THE NEW ISOLATIONISM ........... 8

Traditional Concepts of China ..... 8

The Hoover Thesis .......... 12

Zeroing in on Acheson ........ 17

"The Senator Irom Formosa" ....... 20

Robert A. Tart: "Mr. America" .... 28

III THE ADMINISTRATION'S CASE ........ $38=$

$\mathrm{NsO}-68 . . . . . . . . . . . . .38$

The Conservat1res Attaok ....... 46

Truman's Response .......... 54

The Acheson Testimony ........ 64

Senate Resolution 99 ....... 69

IV AN APPRAISAL ....................... 74

The Question of the Soviet Threat . . 74

The Role of the Troops . . . . . . 76

The Exeout1ve and the Senate . . . . 79

Aftereffects.............. 83

A SELECTED BIBLIOGRAPHY . . . . . . . . . . . 87

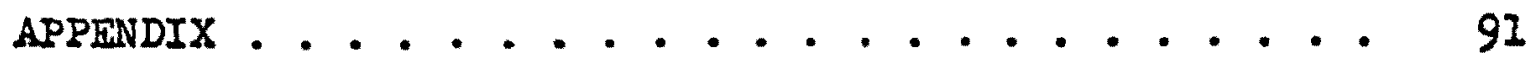




\section{CHAPTER I}

\section{INTRODUCTION}

The winter of 1950-51 rourid the United States envelopod in pessimism, if not actual despair. A senes of 1mpending alsaster seemed to permeate the nation. The mood was solf-generating: each now or1818, real or fanc1ed, prorided fresh fuel for another outburat of national parano1a; the fear in turn brewed new crises.

For most Americans the threat of Communism, in all $16 \mathrm{~s}$ myriad foxm, was somehow responsible for the anxiety and suaplolon whloh beset the country. There seemed to be no end to the "Communist consp1racy." From Korea oame reports of American armies belng chased pell-mell down the penInsula by "hordes" of Chinese Communists, a situation call1ng into question Amerioa's presence there in the first plaoe and also presenting the nagging puzzle of how those I1keable Chinese ever became alsolples of Karl Marx.

The answer to that, claimed some, could only be found If the Department of State were v1gorously invest1gated by proper senatorlal committees. Something smacked of treason at Foggy Bottom. Alger Hiss had already been oonvlcted of perjury. Owen Lattimore had been linked vagriely with Mao tse-tung, and he was therefore suspeot. The name John Carter Vinoent aroused associations with the 1088 or 
China. ${ }^{1}$ And the Secretary or State, Dean Acheson h1mself, had defended them all. Apparently, he insisted on surroundIng himself with a malignant milieu of appeasers and traltars. From Europe the news was haraly more optimiatio. Reports kept indicating that the Red Army, w1th 1 ts 175 div1s1ons (or was 1t 225?) and 30,000 tanks (or was it 45,000?) was posed on the borders of the satell1tes ready to strike and expand godlese Communism on to the helpless peoples of Westorn Europe. Yugoslar1a, $1 t$ was reported, was to be IIrst choice on Stalin's menu or conquest. Tito would have to bo supported. But so would Franco. Indeed, it could only be expected that all of Western Europe would have to be protected from the onslaught.

Presumably, European manpower should proteot Europe. As armchair strateglsts eagerly pointed out, even Yugoslavia and Spaln were not without divisions: the former reportedly had thirty whlle the latter could scrape together twentytwo. Further, 1t was noted that "Greoce could produce and was willing to produce ten divisions. . . ". 2 And of course there was always Britain and France. St1ll, would these Iorces really be enough? Would Americe have to supply: div1slons, too? But how could 1t, already involved wh As1a

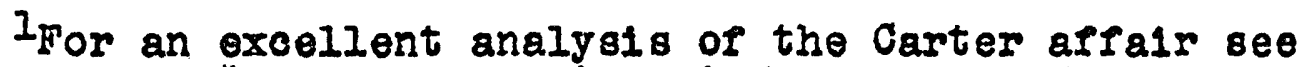
Ross Terr1ll, "When America 'Lost' China: The Case of John Carter Vincent," The Atlantic, November, 1969, pp. 78-86.

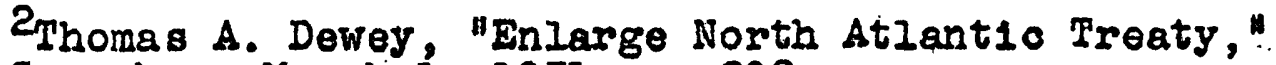
vital Spepohes, Maroh i, 1951, p. 292. 
and the hordes of Chinese Communists in Korea? From these questions emerged the framework for a congressional debate on the future of Amerioan forelgn polioy.

Aotualiy, the "great debate" as 1t oame to be called was really one of a series that began in the late 1940 'a with the China question and continued on afterward with the Macarthur hearings, the quemoy-Matsu controversy, and the role of Amerioan ald to Indochina. Although European defense composed a large measure of the great debate the Far East, and Amerioa's relation to 1t, was never far from center etage. Indeod, for some the maln event was the far East; Europe to them remalned on the periphery.

St111; 1t often seemed difficult to plnpoint the nature of the debate. Adlat Stevenson once auggested it "was mostly a debate about military strategy and not forelgn polloy. . . "3 Others, w1th the benerit of intervening years, have found 1 t more complex:

In short, the debates of 1951-1952 thrashed out the premises which would govern American forelgn polloy for at least the next deoade and a half. At the simplest level, the arguments plvoted on the question of whother Asia shoula enjoy equal priority with Europe in Amerlcan polioy. Overall, the dobate was far moro complex. It became a prime example of how overaimplipied (often unquestioned) premises of one historical era could, almost inevitably, develop into apparently unrelated but far-reaohy 4 golloles affecting lifo and doath in a later era. 4

3Adial E. Stevenson, "There Are No Gibraltars," Vital Speeahes, February 15, 1951, p. 287.

WWalter LaFober, America, Rugsia, and the Cold War, 1945-1966 (New York: John Wiley and Sons, 1967), pp. 128- 
Chronologlcally, it is also dificult to set an exact date for the beginning of the debate. Cortalniy the Korean War had muoh to do with 1t. As the war began to sour for the United States in the autumn of 1950 , it tended to have a catalytic effect on national mood. Rumblings of discontent inoreased in late November and early Deoember as Chinese troops drove American forces out of North Korea and caused them to retreat well into the southern portion of the pen1nsula. The notion the troops would be "home by Christmas" quiokly dissipated and was replaced by a wave of defeatism and mistruat. Much of this national anxiety devieloped into a serious questioning of President Truman's intention, whioh he had f1rst announced on September 9, to make "subatantial 1Deresees in the strength of the Ontted Stetes rorces to be etationed in Festerm Europe in the interest of the derense or that area." 5 But the President's intentions toward

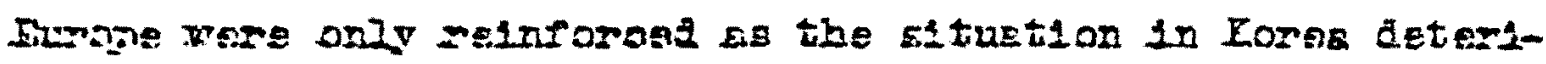
orated in late November. Indeed, the Chinese intervention was all the more reason to suspoct "a world-wide pattern or danger to all the eree nations.." and, consequently, it was now "more necessary than ever that integrated foroes in Europe under a Supreme Command be established at once." 6 In

5U.' S., President, "Statement by the President Upon Approving an Inorease in U.S. Forces in Western Europe" Sept. 9, 1950, Publ10 Papers or The Presidents of the United States: Harry S. Truman (Waghington: U. S. Government Frinting of 1100,19651, p. 626.

30, 6550, Ib." "The President's News Conference of November 
m1d December Secretary of State Dean Acheson flew to Europe to do just that.

In Congres, however, some members reacted to the Korean Imbrogl10, and tho Prealarnt'o statements ooncerning the related posalb1lity of Communist expansion 1nto Western Europe, with something just short of pandemonium. Senator Kenneth MoKellar, Democrat of Tennessee, and then dean of the Senate, solemnly summed up the state of affairs in Congress and in the nation:

I have served in one or the other of the two Houses of Congress for a period of nearly 40 years. During that long perlod of time I do not belleve I have ever seen the Members of this body and the Members of the other body, or the people generally, ever working at suoh oross purposes. I do not belleve I have ever seen then so critioal of one another.

McKellar himself was hardly an impassive bystander. Indeed, in his view the 18 sues being debated reached truly momentous proportions: "Shall the greatest Constitution ever written and the greatest government ever devised by man and freest and most successful and most prosperous people on earth, remain as presently set up; or are we to be taken over by Communists who belleve nelther in God nor $\operatorname{man} ?{ }^{8} 8$

- Senator MoKellar's rhetoric to the contrary, the Infldels were not yet at the gates. Nevertheless, his

TKenneth McKellar, c1ted by Anon., "The 'Lame Duck' Session Features Anxi otj and Taxes," Congressional D1gest, January, 1951, p. I.

IIb1d. 
remarks reflected the confusion which resulted from a fundamental and plaguing question: by which gate would they strike? The Adminlstration's response was to opt for a flexible defense, one that would be capable of defending Europe as woll as Asia. This position was decried by opponents in both parties who argued that the threat in Europe was remote while the one in the Far East was real and 1mmediate. Coupled with this concern was the supposed danger, darkly hinted at by some, that a flfth column was operating out of the highest eohelons of government, and $1 t$ was responsible for many forelgn polley declsions. Such vlews were in turn roundly attacked as being "1solationist" by pro-Administration forces.

The 1solationist tag attached to the Administration's oritios offered a quick and neat label, but it did not adoquately define the opposition's views. To argue that the1s viewe were simply a resurgenoo of "traditional 1solationism" was to be guilty of mouthing a vague generality. Historian Arthur Schlesinger, Jr. Was more spec1110 when ho attempted to catalogue the group. He found that the 1solationism of an earlier era--that of Senators Norris and LaFollette, for example--tended to be "afflrmative" whereas the 1solationism of the present period was found to be "negative." He differentiated the two by arguing that "one was moved by hope Ior Amer10a, the other by hatred of Burope." Further, "One shunned Europe the better to change America; the other, the 
better to keep Amerloa from ohanging." 'In Schlesinger's plew, then, there was something inherently more repugnant about the new 1solationiam.

Anxiety of this sort among liberals increased when 1t became evident to many of them that the proponenta of the new 1solationlam often seemed to offor no spec1f10 solutions to forelgn polloy problems other than to flre away at the nazy target of "traitora in Washington." Others proressed to see the adrooates of the new 1solationiam following a course that could eventually lead to a "prevent1ve" war-nuolear etyle. While these viewe may have had some validity, they usualiy falled to deal with the reasoning, such as $1 t$ was, that las bohind the conservative position.

9Arthur M. Sohles1nger, Jr., "The Now Isolationism," The Atlant10, May, 1952, p. 35. 


\section{CHAPTER II}

\section{THE NEW ISOLATIONISM}

\section{Traditionel Concepts or China}

Much conservative thinking in rogard to Chlna, and Indoed all of the Far East, conslated of a curlous blend of hlstorical fact with a smattering of Realpolitik, a generous portion of missionary zeal, a discornible trace of nineteenth contury business ethic, and a sizeable amount of Midwestern intuition. What omerged was a political stew of confusing and questionable content. However, since much of this concoction had been spoon-fed the American public for years, 1ts ingredients require a more careful examination. First or all, many conservatives simply could not-nor did they wish to--shake offithe propensity to v1ew As1a, ospeolally China, with a special nostalg1o favor1tiam. Ch1na would always remain in their minds as that humblo sleeping glant whlch could only be awakened by a slow and somewhat painful transfusion of capltalism and Christianity. Only by following America's example would China ever progress. Th1s bollef was so ingrained in a certain segment of the Amorlcan public that it literaliy became a form of gospel. Senator Kenneth T. Wherry, for example, reportedly adaressed a orowa in 1940: "With God's help, we w1ll lift Shanghal up 
and up, ever up, unt1l it is just like Kansas City. ${ }^{1}$

While dazed wonder would be the common reaction to such an utterance today, it was reoel ved with "w1ld cheering" 1n 1940. Senator Wherry's exhortation may have been somewhat of a olassio even for that period, but it nevertheless reflected the type of information and thinking which many Amertcang gullibly aocepted concerning China.

Undoubtediy much of this was due to years of reports sent back from Amerioan m1ssionaries in the Orlent. Orten, In fact, looal churohes provided the only link between small-town America and Ohristian progress in far-orf:Asia. Ono authorlty has noted:

The Far East (1nciuding southeast Asia and India) absorbed more American Protestant missionaries than any other section of the globe. The education carried on through the Protestant churches of the United States to acqualnt the supporting constituenoy with what was belng done gave to millions information, usually sympathet1c, about the peoples, chltures, and problems of eastern and southern Asia.?

The traditional economic policies assoclated wh the "Open Door" prinolple also helped Americane to adopt a patronizing attitude toward China. Presumably, what was good for American businese was aleo good for Chlna, of at least eventually woula be. Of course, Chlnese merchants orten resented this notion, and occasionally American interests surfered local reverses when rebellions broke out.

IKenneth T. Wherry, c1ted by Erio F. Goldman, The Cruoial Decado--and After (Now York: Vintage Books, ig60), p. II6

Kenneth Soott Latourette, The American Record in the Far East, 1945-1951 (New York: 'The Macmillan Company, 1953), p. 12 . 
St1ll, ab1de from following a polloy of "gunboat alplomacy," the eupporters of American interests in China never seriouely suggested that America go to war to defend those interests. 3 Ourlously, that developed as a result of such thinkIng was in fact a policy or contradiction. As Professor. Tang Tsou has noted: "While reluctant to pey a heavy price to promote her 1deals and to protect her interests, the United States was unwiling to relinquish her principles and her hope of future gains. Wly Undoubtedly, thls was in part due to the rise and continued rule of the Nationalist regime under Chlang Ka1-shek. As long as Chlang remalned in power, American economic interest seemed to be in little danger, due in large part to his dependence on American a1d.

Another American concept concerning China developed during Worla War II when most of the Amorican public was persuaded to aooept Ch1na as a "great pover." Of course China never really did belong in this category, but such 'rlotion was nocessary in order to insure her continued part1olpation in the war againgt Japan. President Roosevelt. and his Seoretary of State even made certain overtures suggesting that China would "be granted a high place among the nations" of the world at the conclusion of the war. 5 While

3Tang Trou, Amerloa's Fallure in Ohina (Onlcago: The University of Chicago Prese, I963), p. 25.

4 Ibia.

5yerbert Fe1s; The Ohina Tangle (Now York: Atheneum, 1965), p. 95 . 
there were some offlcials at high levels of government who held serlous reservations about the practicallty or such a proposal, 1 t was unfortunately acoepted by most Americans as a sensible and realizable goal. Th1s was partlcularly true of conservatives who had long been enchanted by the possibilities of Ghina's rehabilitation and emergence as a world power, thanks to Amerlcan laith and know-how. St1ll, there remalned the occaslonal conservative who felt that China's Importance lay not in commerce, Christlanity, nor as a potential great powor. Rather, her 1mportance to the United States lay in her strategio looation. Th1s line of reasoning held that America's concern for Chine should be based solely on the securlty considerations of the United States 1t self. A proponent of suoh thinking, Representative Walter Judd, argued before the Exeoutive Club of Chlcago in February of 1951:

It was not necessary that they should have a good government in China. That was desirable, but wholly secondary. It did not necessarliy need to be a demoorat1o government, an honest government, or an efflclent government. The key thing was that the manpower and the resources and the basis of China be under Chinese Irlendly to the United States, and not under the gontrol of potential enenies of the United States. 6

Congressman Judd's arguments are of 1nterest for several reasons. First, they hint at some sort of Bismarckian sophistioation, a rather strange taok for a man who had

Walter Juda, "How Can We Be so Stupidi" V1tal Speeches, March 1, 1951, p. 294. 
spent a good portion of his ilfe engaged as a m1861onary in Chlns. It would normal iy be assumed that a former olergyman would not find tho notion of a good govemment in China to be a "wholly seoondary" consideration. Possibly such a discrepancy could be explained away by suggesting that Dr. Juda's ecolesiastical interests had simply given way to a sense of hard-headed power pollt1os. But what seems more 11kely $1 \mathrm{~s}$ that here was an example or a pro-Chlang Republ1can who had become so worked up over the posalble fate of h1s favorite Aslen reglme that he was reduod to employing arguments that were both contradiotory and misleading. Dr. Judd's concern, howerer, was not with the type or manner of argument he used; rathor, he was only interested in the United states continuing to both vigorously support and enoourage the actions of Chlang Kai-ghek. If this meant ho was to become a practitioner or Realpolitik, so be 1t. In essence, then, whlle hits arguments may have added a now degree of sophistry to the great debate, his motives and reasoning were much the same as those of other conservatives. Unfortunately, they also reflected their weaknesers.

\section{The Hoover Thesis}

As previously noted, opposition to the forelgn policy or the Truman Administration mounted ateadily arter the "10ss" of China in 1949. With the advent of the Xorean War, 1t momentarily subsided owing to the necessity or supportIng a President and country engaged in an ABlan war againat 
Communism. But when it became clear in November of 1950 that the war in Korea would not be over by Chrlstmas and the President was not going to allow General MacArthur to bomb Chinese targets in Manohuria, opposition onco again quickig mounted. Its tempo inoreased even more when it becamo appatent that Truman was determined to send additional troops to Europe. Its eventual high water mark was reached on December 20, 1950, when former President Herbert Hoover delivered a national radio addreas whioh $1 \mathrm{~s}$ generally recognized as the opening salvo in the "great debate" of the coming months. In 1 t can be found many of the 188 ses with which most of the new 1solationists oould readily 1dent1fy. A clue to Mr. Hoover's remaris can be gleaned from his repeated references to the United States as "thls Western Hemisphere Gibraltar of Western Civilization"--terminology that was to provide Administration defenders with the opportunity to oastigate him for his "fortress America" outlook. Baslcaliy the Hoover Gibralter phllosophy held that so long as the Paolfic Ooean and Japan, Formosa and the Ph1lipplnes remalned as one frontier, and the Atlantio Ocean (along w1th Great Britain, "If she wishes to co-operate") remained as the other, the United States would be guaranteed a defense posture that would be sufficient to her noeds. To foplement such a program, however, it would be necessary to "arm our alr and naval forces to the teeth." (Hoover was to add in a later rad10 speech that this only made good sense sine "the 
whole Korean tregedy 18 developing proor that the way to puntsh aggressors 1s from the alr and sea and not by land armles." 7 Oonversely, Bince Americe would no longer need to maintain large armies elther on the mainland of Aala or in Europe, such forces should be removed. For any future war using large numbers of Amerlcan ground troops would prove disastrous. Cautioned Hoover:

Wo must face the fact that to comm1t the sparse ground forces of the non-Communist nations into a land war against this Communist land mass would be a war without a victory, a war without a succeasful political terminal. Any attempt to make war on the Communist mass by land Invasion, through the quicksands of China, India [?] or Western Europe 18 oheer folly. That would be the graveyard of millions of Amerioan boys and would end. In the exholistion of this Gibraltar of Western Civilization.8

Hoover, apparently Impresied by the Nazl defeat at the hands of the Red Army during World War II, repeatedly warned againet American soldiers becoming involved in a war against a "Kremlin-directed horde." Thls concern about employing large numbers of American ground forces in almost any future conflict was widely held by a number of the Administration's opponents, if not by a alzeable portion of the American pub110 1tself. It became, in fact, a sort of fundamental maxim: American "boys" in large numbers almply could not be saorlficed in battles against faceless hordos capablo of overpowering them with sheer numbers alone.

7herbert Hoover, "We Should Revise Our Forelgn Pol10108," V1tal Speeches, February 15, I951, p. 264.

8 Herbert Hoover, "Our National Polloles in this Cr181s," V1tal Speeches, January 1, 1951, p. 165. 
During the coming weeks, whlle Hoover both modifled and expanded his thesis, many of his speeches continued to deal w1th the specter of Rusalan and/or Chinese hordes. Gradually, however, the hordes were jolned by new allies, factors he referred to as "General space, General Winter and General Scorched Earth." Any attempt to engage Russian or Chinese amies would also have to reckon with these factors, wamed Hoover.

Some observers were to detoot another concern of Hoover's. He seemed not only to be worrled by the strategy or national derense but also the cost of 1t. Often 1t became difficult to sort out his priorities: defense agalnst Commundsm or defense agalnst excessive defense of Communism. At times Economic considerations definitely won out:

The unbearable strain on our economic system will come from trying to do five things at the same timo. That 18, to maintaln armies in the Paolric; to build up an air force; a naval force; to fumlsh munitions to nation 0 who are determined to defend themselves; and bey ond that to send land armies to Eyrope. Our oconomy cannot carry this load for long.?

The uproar over Hoover's original speech of December 20 was both instant and no1sy. Admlnistration supporters were quick to ola1m that his interpretation or what American forelgn pollcy should be amounted to little more than oldrashlonedisolationism. (In later weeks Hoover and his derenders were to be labeled "neo-1solationists," a term,

9perbert.Hoover, "We Should Revise Our Forelgn Pol$101 e 8, " \mathrm{pp} .264-265$. 
accoralng to one observer, that was applied to those wishing. to fight in China but not in Europe. $)^{10}$ Dean Acheson remarked that any w1thdrawal of Amerlcan troopg from Europe would only "enable the soviet union to make a quiok conquest of the entire Eurasian land masg" and that would be "catagtrophic to the United States." II Conservatives were just as quick in cla1ming Hoover's megage had been misinterpreted, perhaps intentionally. Columnist Raymond Moley, for instance, wrote 1t was lnot only incorrect but very dangerous to call the Hoover plan isolationism. A foreign policy that proposes an area of American power, from the North Sea to the Sea of Japan and from the North to the south Pole, cannot be called burying our head in the sand."I2 Harming to his subject, Moley wont on to note that Hoover had also made it clear that the "Communist empire" was not nearly as eecure as it appeared. In fact, it was extremely pulnorable:

The Red China regime advances 1ts borders in weakness rather than in strength. Its efforts to push into southeast Asia extend 1 ts capac1ties to the breaking point. There are hunareas of thousands of Astatics behind the Red lines who can be more and more activated by the virus of revolt. We must fight with the underground there as well as in the communist sateliltes in Europe.13

10Norman A. Graebner, The New Isolationism (New York: The Ronald Press Company, ig56), p. 27.

Il"Acheson: Jo1nt Defense," Newaweek, January 1, 1951, pp. 10-11.

12Raymona Moley, "The Hoover Challenge," Ible., p. 60. 13 Ib1a. 
Here Moley etruck a obord that was to be heard again and again throughout the great debate. Somehow, the notion that large-scale, ant1-Communist, clandestine activities Here occurring behind the iron and bamboo curtains becane w1dely accepted by the Amer1can Right. Yet wh1le conservatives placed a great amount of faith in this beller, they could never muster up any bard evidence which might support such'a thesis. References auch as Moley's about aiding "underground" act1vity were constantly belng made, but most of them dealt with generalities with few specirio suggestions as to implementation. Many of the proposals were based more on a sense of romant1c1sm than realiam. Where they or 1ginated is hardly a mystery; many of them were almply based upon the propaganda of refugee groups ach as the Nationalists on Talwan. Chlang's government, in particular, was noteworthy in its attempts to convince the United States that guerila-inltiated actions were occurring with 1noreasing frequency on the mainland. Again, proor of this was unobtalnable, but lack of 1 t never troubled the true bellevers of Chlang in America.

\section{Zerolng in on Acheson}

As they sought to defend Hoover and his forelgn policy proposals, many conservatives searched for a weak ink in the Adm1n1stration's armor. In Secrotary of State Dean Acheson they felt they found it, and by Deciember of 1950 the 
Secretary was being subjeoted to increasingly virulent attacks from the Right., As alslilusionment with sorelgn pol1cy 1ncreased, even more moderate conservatives began to view him as the prime viliain in the Truman Adminiatration. Ee beoame the scapegoat for Admin 1stration oritics because as one observer noted, "he was the easiest target in sight." Aside from pólloy decisions alone, his very character seemed reason enough to 1norease the invectlve. Concerning this onslaught, one historian has noted: "His personallty, his genteel New England background, his feultless grooming (one Congressman habltually referred to him as 'that goddann Iloorwalker'), his atr of arlotocratic detachment, and his inteliectual superiority made him superbly rulnerable." 14 In other words, not only was Acheson a weak and recklese 11beral, to many he was also a stuck-up snob. A more "ant1American" caricature would be diffloult to 1magine. In faot, thererseems little doubt that in the eyes of bis domest1c enem1er, Acheson assumed the proportions of an American Chamberlain. Similarly, he would be accused of leading Amerioan diplomaoy through one Munioh after another. And, like Chamberlain, he would be denounced for practicing "appeasement."

In a very real senee the semantice of those attacks became more 1 mportant than the attacks themselvea. "Appeasement" emerged as the best example; 1 t seemed the only lesson ${ }^{14}$ Graebner, p. 65. 
tho American Right learned from World War II was the use of this term. Nevertheless, Irom its use the Right was ablo to squeeze an enormous amount or political mileage. When employed in conjunction with an attack on Acheson, it was. effective in conjuring up the image of a dapper and debonals diplomat bowing and scraping before a leering Communist bully. Consequently, many Amerioans were conaltioned into assuming that China was "lost" in 1949 booause or "appeasement" and the rest of Asla would go the same way unless the spineless Acheson were removed from office. Even Hoover in h1s speeoh managed to matter-of-factly insert 1t, caution1ng, "We should have none of appeasement." "Appeasement," then, became an overworked but incredibly potent polltioal shtbboleth for arousing Inalgnation at Adminfstration policy under Acheson's control.

The attacks against him accelerated at such a clip that tho President was foroed vigorously to defend his secretary at a press conference in December:

These recent attacks on $\mathrm{Mr}$. Acheson are old, in the sense that they are the same false charges-and I emphasize that false chargea--that have been made time and again over a perlod of months. They have no bais s in fact what ever.

It 1s the same thing that happened to seward. Pres1dent Lincoln was asked by a group of Republicans to dism1ss Seoretary of State Beward. He refused. So do I refuse to dism $18 s$ Secretary Acheson. If

15U. S., President, "The President's News Conference. or December is, 1950 " Publlo Papers of The Pregidents of the United States: Harry S. Truman Washington: U. $\$$. covernment Printing Oxf10e, 1965), p. 751 . 
While his allusion to Lincoln was overdrawn, Truman's trust in the ablilty of hlo seoretary of state was unshakable. He know Acheson to be both loyal and hard working. Horeover, he felt that even with Achoson gone the debate would cont1nue. In Truman's view the conservatives "wanted Acheson's soalp because he stood for my polloy. "I6 Much of this "soalp hunting" Irankly perplexed the President, and ho was later to wonder what had happened to the blopartisansh1p approach to forelgn polioy that had prevalled when Arthur Vandenberg had spoken for the Republican Party. Since Vandenberg's death, Iruman found $1 t$ distressing to note in the Republican party "the rise of a faction.. . that seemed to know no approach to government except to belittle, to denounce, and to negate."17

\section{"The Senator From Formosa"}

The voloe of Republican Serrator W1ll1am F. Knowland of Callfornia was to emerge as one of the most vocal and persiotent in deploring and denouncing the forelgn policy of the Truman Adminlatration. Knowland gradually became the unorficial prolooutor for the Republican Party on the subjeot of Far Eastern affairs, and next to Senators Taft and Wherry, he probably headed the liat of. Truman's "1rresponsible

16 Harry 3. Truman, Memo1rg (Garden C1ty: Doubleday \& Company, Ino., i956), II, 430 .

17Ib1d. 
faction." While most of his senatorial oolleagues deroted a good portion of their efforts to disoussing the question of European defense, Knowland Iimlted most of his to Asia. In the Senator's mind, Asia was oertalnly no mero backwater; Indeed, ho often proclasmed that the future of Europe was clearly dependent on the coures of events in the Far Fast. He was fond of quoting what he termed Lenin's "sound observation" that "the road to Paris is through Pelping."18

Taotically, Knowland has to be given credit for hls remarkable ab1l1ty to explo1t the semantios of the Cold War. In regerd to "appeasement," for 1nstanoe, he never t1red or uaing what had to be the best one-liner on the entire subject, one that he was to employ on numerous occasions: "A vast majority or them [As1ans] are convinced, I believe, that the road to appeasement is not the road to peace and that appeasement, as at Munich, is but surrender on the installment plan."19 Thus in one rell swoop he managed to rattle an already frightened Amertcan public by conjuring up bitter memories of Hitler, Chamberlain, World War II, and Installment buying--a memorable leat evenifor a politiclan. On another occasion he insisted thet while Asians still admired what the Un1ted States represented, such good w1II

18. S. S., Congresst onal Record, s2d Cong., lst Sess., 1951, XCVII, Part 1, 157.

I9will1am F. Knowland, "A Faterul Hour: Necessity for Combating Aggressive Communism in Abia," V1tal Speoches, Deoember 15,1950 , p. 155. 
could be inoreased if only America would "aran the line" against Communiam. 20 "Drawling the 11ne" had become an 1mportant and catchy phrase in the knowland lexicon. The 1dea seemed to be that tricky forelgn policy disputes could be settled by I1ne-drawing, wuch as a schoolboy might etch out a line with his toe in the dust of a playground and dare the local bully to step across 1t. However questionable the valia1ty of such an analogy may have been, Knowland aensed the Amerlcan publio acoepted 1t, and that was all that mattered.

In his speech to the Senate of December 4, he outlined a pollcy that if implemented would presumably have held the IIne agalnst Communsm in Asla. First, as the result of a recent gunket to Korea, he urged that Amert can alrcrart be allowed to pursue Chinese Ilghters across the Yalu River and 1nto Manchurla. Knowland was yet another of the alr and naval strateglsts that the American R1ght produced in no short supply during this period. As a consequence, they argued that 1f only the "off $11 \mathrm{mlts}$ " slgns were removed, Amerloan at $r$ power would end the war in Korea. 21

Knowland next turned his attention to Japan and called for "an early Japanese peace treaty, with Japan having means, under proper supervision, of particlpating in the colleotivo seourity system against aggression. ... 22 Most

$$
\begin{aligned}
& \text { 20U. S., Congress1onal Reoord, p. } 158 . \\
& 2 I_{\text {Knowland, p. } 156.22 \text { IbIa. }}
\end{aligned}
$$


conservatives wholeheartodly concurred on th1s point, sens1ng, perhaps before most liberals, that Japan would const1tute an 1mportant anchor in any dofensivo screen in East Aa1a. (Orten, however, the importance of this view was lost amldit the metaphorloal cllohes of a cold war opportunist as when Senator Joseph McCarthy prophesica: "If Japan Ialla, the ontire Pac1f10 Ialls, and we w1ll have a Red Pac1l10 washing our western shores wh th 1 ts communist 10 athe1at10 erosion." 23

Knowland then turned to his pavorite top10: economio and milltary ald to Ghlang Kal-shek's regime on Formosa. Fe olalmed Chlang's armed forces were over $81 x$ bundred thousand men strong, a force larger "than all the other non-Communist nations of Asia put together."24 such a force was simply inds spensable to the eree world. It would act as a powerful deterrent agalinst any ruture Chinese Communist aggression. Moreover, if supplied with the proper equipment the Republic or Ohina woula be able to stimulate 1ts "non-Communist. guerrilla forcer of over 1,000,000 men" whtch were operating behind the 1ron curtain. 25 Further, Chinese Nationalist forces vould be able to conduct "ralds" along the coast of Chine which would have the effect of forcing the Communists to 61phon troops away from Manchuria and Korea, thereby relleving the beleaguered United Nations forces 11ghting on

$$
\begin{aligned}
& \text { 23U. s., Congressional Recora, Part 2, p. } 2396 . \\
& \text { 24 Ib1a. } \\
& \text { 25Ib1a. }
\end{aligned}
$$


the peningula.

Another aspect of Knowland's drawing-the-line plan consiated of glving "tho Chinese Communists 48 hours to stop their aggression in Korea and to get back acrose tho Yalu River.". If they refused Knowland would have had the United States ark all member states of the United Nations to "pledge" to wltharaw any recognttion that had been afforded that regime. Such action, Knowiand maintained, would "weaken the prestige of Mao tse-tung at home and [would] wake that government 1]legal in the eyes of the people." 26 Whilo he did not speolf1cally say so, it seeme apparent that Knowland felt such aotion would have amounted to a diplomat10 oatastrophe of such a magnitude that the Communist government would have toppled from sheer despalr.

Finally, Knowland adrocated "an Immediate naval blookade of the entire China coast. . " which would "not permit the entry or exit of a vessel of eny nationality." 27

Strangely, much of the Senator's thinking--and this was true of many other conservatives as well--seemed to rerleot a fantastio lgnorance and/or deliberate mlareading of what had been oocurring in China for the previous twenty years. The fanatical paith he held in Chiang and bis Kuomintang 18 almost mystlfying. The only explanation that can aooount for such devotion was that Knowland could not bring himbelf to accept the fallure of the Nat1onal1sts. In going 
to almost any length to buttress the Chlang reglme, he was reduced to edvocating a policy whose inception would have proven fatal not only to Chlang but quite possibly to the United States 1tself. Th1s, at least, was the way tho Truman Administration viewed proposals of this sort. There Is absolutely no evidence to inaicate, for example, that a series of "raida" along the coast or China would have had any marked effect on the Korean conflict. The claim that there were one million dedicated guerrillas operating on the Malnland was probably pure fabrication, 28 but it was 1mportant because by 1tg very suggestion a romantic 1mage of a courageous but vastly outnumbered group of freedom fl ghters was instillod in the mind of the publ10. The notion that Nao would have witharam from Korea as the result of a forty-elght hour ultimatum, leat he $108 \theta$ "prestige," was ludicrous.' Again, it Indicated that Knowland had not the vaguest 1 dea of what Mao and his revolution were all about. And the proposal that a blockade of China's coast with the right to turn back vessels of "ang nationallty" amounted to a declaration of war agalnst China and quite possibly against any other nation which might choose to challenge such a ukase. Clearly, in Deoember of 1950 the United States did not intend to prooeed along such a path.

28 When querled about this statist10 by the author, Senator Knowland chose not to reply. 
While Knowlend's jingolsm was successful in geining him further publicity and in extending the attack on the Adminiatration, it also had the effect of mystifying some of his nonatorlal onlinagiea. To aome, no mation how the nent ator sought to digguise certain unpleasant eventualities, hla remariks seemed to offer the very real possibility of an all-out war with Communist China. Buch thinking naturally led them to wonder if this would mean a land war on the Asian continent. As a result of such disquieting thoughts, Knowland hastened to assure his fellow senatorg that nothing could have been further from his own mind:

I have never favored sending a United Nations land army into Manahuria or into China. I have never favored sending an Amerioan Army into Manchuria or into China. I think that would be a fut1le policy. It would be the same mlstake that Napoleon made in Russia, and that others have made in the invasion of Russia. I would not operate in an area of tarrain in which the eneray is superior to us by 10 to i. I would operate in areas where wezare guperior to them by many times that number to one. 29

The question remalned, however, juat preclsely what were those areas where the United States was "superior to them by many times that number to one"? To Knowland the answer was olmple: In sea and atr power. Amertcan oea and air power, coupled with Chiang's American-equipped armies, would be capable of dealing the Communists a blow from which they would never recover. St1ll, skeptios found it difficult to 1magine, given the history of Chiang's military record in

29U. S., Congressional Record, p. 162. 
China, that Nationalist armies could ever wrestle back control of the Mainland, even with the added factor of American sea and alr power. Knowland's contention was eventually to become one of the weakest weapons in the arsenal of the Right.

As mentioned above, because of h1s fascination with Asia Knowland found little time to devote to Europe. Even during the height of the debate he could only bring himself to propose half-heartedly that America allocate one division for European duty for every six divisions fielded by the Europeans themselves. 30 The proposal got nowhere, and Knowland seemed not to care, a reflection, no doubt, of h1s general lack of interest in the entire European 188ue. If the subject of Europe did occasionally strike a spark of Interest in $\mathrm{h} I \mathrm{~m}$, it was over a related matter rather than Europe 1tself. In making h1s proposal on a ratio of Amer1can divisions for NATO, for example, he saw the importance of Europe IInked, of all places, to Africa: "Certainly $1 t$ 1s vital that Europe not fall into the orbit or international communism. If Europe 1s lost to the eree worla, the strategic bases and materials of Africa would be diffcult to hold. The bulk of the uranium for the American atomic development comes from Africa." 31 It 1 s of interest to note that while the senator found the uranium ore of Africa to be of prime importance to the United States, be

$$
\text { 30 Ib1a., p. 158: , }{ }^{31_{\text {Ib1a. }} .}
$$


could not bring that same thinking to boar in regard to the coal, Iron ore, and Industrial capability of Western Europe. Western Europe was 1mportant because it represented a steppingetone to Africa, not because of any worth of 1ts om. Because of this factor Knowland felt Europe would have to be defended, but hopefully not with American ground personnel In large numbers. Exactly how Europe should be defended Enowland ald not apell out. Apparently sat1seled that he had done his duty in explaining how the tide of Communism oould bo reversed in the Far East, he leet this chore to his close friend, Robert A. Taft. .

\section{Robert A. Tart: "Mr. America"}

Herbert Hoover had become the elder statesman of the new 1solationist movement, W1lilam Knowland had become 1ts Asian anthority, but the maestro of the entire effort was Republican Senator Robert A. Tart of Oh10. By 1950 Tart had arrived at an extremely 1mportant post for a Republican in the Senate: he was chalrman of the Senete Republican Pol1cy Committor, having risen to this position through the ranks of the Republican Party with ramariable swiftness. Whatever the attributes are that propel a man up the ladder of Amer1can political success, Taft seemed to possess them. During the 1940 's he became establishod as the Republican ro100 in the Senate on domestic affairs. After World War II he also sought to become an expert on forelgn affalrs. He gradually 
slipped into this role and assumed it completely with the death of Arthur Vandenburg in 1950. It was not long before he somehow began to personify what proper oonservative thinking ought to be all about, and beoause of this ability he was nlcknamed "Mr. Republican." One hlatorian has suggested, however, that by the time of the great debate he had become "Mr. Amerlca," so well ala he express "the publio's ambivalent 1solation1st-aggressive state of emotion" on world affairs. 32 An examination 1nto Taft's ph1losophles does much to confirm the appropriateness of the "Mr. Amer$1 \mathrm{CQ}^{\prime \prime}$ eplthet, and it also alds in explaining how the Senator became the acknowledged leader of the "new 18olationiats."

First and fundamentally, Taft had always been a vigorous and sincere ant1-Communist. He could foresee no worse ov1l. Throughout his senatorial career he fought Communiam internaliy and externaliy. And as often seems to bo the case with conservatives, Taft recognized the danger of Communl sm but was apparently 1ncapable of seelng any threat whlch mlght ohallenge the Republ10 from the other end of the political spectrum. William S. White, a generally Irienaly blographer of Taft's, has revealed:

In the war years and later he ridiouled any theory that Naz1 Germany had ever raised any danger to tho United States. He sald to me as late as November of 1951 that at no time had Germany menaced the security of the United States and that there would have been

32John W. Span1er, The Truman-MacArthur Controversy and the Korean War (Cambridge: BeIknap Yress, 1959), p. 156. 
no menace even had the Britiah fallen... 33

His passionate denouncements or Communism wero direoted primarily againgt the Soviet Union which he oaw as the prime mover of all Communiet activity everywhere. "Sovlet Rusg1a," as Tart preferred to call 1t, had broken overy treaty to which it had ever been a s1gnatory. It had promoted the military actions of both North Korea and Chlna. There was "Bufficient evidence," he warned in a speech on the Senate floor, "or a determined plan to communize the ent1re world, whlch oan be olearly envisloned from the writIngs of Lenin and Stalin, just as Hitler's intention could be found in Mein Kampr." 34 In the Senator's mind, proor of the existence of such a "plan" could be found by taking note or how far the consplracy had progressed within the United States 1tself. He 1nalsted various organizations and labor unions wore boing inf1ltrated, as wao the government itsolf."35 He had no apparent diffculty in relating the machinations of Soviet 1mperialiem with domest10 1seues Ineide the United States and even, by Implication, with an American government controlled by a party of which he was not a member. Sly allegations of this sort always boosted his stock with fellow Republioans but over a period of time caused moderates to wonder about the credibllity of bls

33w1lliam S. Wh1te, The Taft Story (New York: Harper \& Brothers, 1954), p. 151 .

34J. s., Congressional Reoord, p. $56 . \quad 35$ Ibid. 
arguments in matters dealing with forelgn affairs. It gradualiy became evident that his own style may have been one of tho chlef obstacles in his leglslative defeats.

W1th Taft's concern over the conspiratorial power of - the Sovlet Union boing what it was, it would seem probable that he would have boen in the forelront of the fight to Inorease the strength of NATO forces in Westem Europo. But, strangely, such was not the case. He actively opposed American participation in any European derense program except under cortain specifled conaltions. The basis for h1s opposition was manifold and often oddly contradictory, at least when compared with his 1 deas on tho defense problems of the Far East.

Although the soviets may have been engaging in various sinister activities, Taft sincerely felt that they were not Interested in launching any massive invasion into Western Europe. In fact, he felt American reaction to the possibility of such an attack might well cause the Sorlets to ini-

tiate 1t out of self-derense:

The course we are pursuing will make war more I1kely. If this great international force which we envision is gradually built up, the Russians for a while wili gradualiy increase their strength, but it seems obrious that if they think the Allies are gaining on them too rapidly, they can always begin the war. However derensive and pac111c our intentions, to them the buliaing up of this forge must look ilke aggression when it is completed. 36

Taft went on to note that he had been unable to discover any 36Ib1d., p. 60 . 
evidence whioh indicated the Soviets were preparing to Invade Western Europe. Further, he wondered, for what wero they walting? Surely it made botter sense for them to strk we wen western defensive positions wero weak rather than walt for the completion of an American and allied build up. All of this was reason onough, he clalmed, to be against any inoreased American rolo in NATO, Just as he had been opposed to the very formation of the Atlantic Pact in 1948. Apparently accepting any support ho could find for his argument, ho was not above pointing out the Atlantio Alliance "abandoned the whole princlple of the United Nations, "37, wht ah was a rather curious statement, for Tart since he had shown little inclination to derend $U$. N. prinoiples in the past.

Orten, however, it did appear Tart was unsure of his own.position. From time to time he noted, albelt besitantly, that if Western Europe fell to the Soviets the threat to American liberty would be considerable. St11l, he oautioned, it did not follow "that because we desire the freedom of every country in the world we must send an American land army to that country to defend 1t."38 After all, Europe had more than a sufflclent manpower base from. whlch to raise an adequate army to repel any Sov1et attack.

37Robert A. Tart, "United States Relations with Westerib Europe," V1tal Speeches, Jure 15, 1951, p. 518.

38. S., Congressional Record, p. 1120. 
Amerloa need only oupply the armament. No Amerlcan divisions would be necessaxy. If the situation became really desperate, however, he was wliling to employ American atr and oea units.

Taft seemed to base at least part of his m1litary thinking on his own reading of the outcome of World War II. In his mind two simple lessons had emerged from the war. First, the Russians had created a tremendous land army that was almost unstoppable; and second, the Amerlcans had put together an alr force whl oh proved to be, in his own worda, "the decisive factor in the winning of the war."39 Given these two axioms, Taft coneldered it merely common sense to minimize the role of American ground forces and to maximize Amerloan alr power. Further, olnce the U. S. Navy was V1ctorlous in the Paolfic, its role in any coming defensive strategy would also have to be emphasized.

In short, in a military sense Taft nurtured a. strategy that suggested a philosophloal cross between Alfred T. Nahan and Curtis LeMay. That such a combination would be effect1ve was never doubted by the Senator:

- My own view is that we do have the capacity to secure a practical control of $\mathbf{s e a}$ and alr, throughout the world. I bellevo we do have the capacity to build up an alr force so superior to Russia as to give us control of the alr over this country, over the oceans that surround this continent and everywhere, except perhaps over Rusaia itself. I bellove that should be the firet priority, and I have not heard any substantial objection made 
against this priority. In theory tho administration agrees. 40 In practice they sem to prefor land

What accounted for Taft's infatuation with alf and naval power? Possibly the best answer is supplied by Wh1te:

He told me in 1951 , in the perlod when he was rirst clamoring for a reassessment of forelgn-m1litary polioy to givo practically all the emphasis to seaal $r$, that his proposal had been influencod, If not shaped, by "certain reading" he had been doing. "What reading, Senator?" he was asked. "I have gone very careruliy again over the history of the Napoleonio campalgn," he repl1ed. "Wellingt on at Waterloo accomplished what he ald with only twenty per cent of h1s troops from the United Kingdom and the rest mercenaries."

He had, in short, by a strange paradox, a compulsive bias toward the most traditionaliy professional of all professional military opinion. He believed that what Britain had done in tho eighteenth century by her control of the sea the United States and Britain, with Britain of course the lesser partner, could do past the halfway mark in the twentieth century.

In this regard ho saw a1r power as only an extension of the sea arm. And beceuse of his hesitations, because of h1s 11 vely but uncomprehending compaseion for the nasty job of the infentry, he gladly accopted one of the apecial prejudices of the oldfashioned Admirals-tholr prejudice against a war or mass and especially against having to use vast numbers of amateurs in the shape of quickly impressed clvilians. Taft could readily underetand this; he did not like amateura in polltical campa1

Aa with Hoover, Taft also feared the possible economic roperouselons of a third world war. War would have meant

$$
\begin{aligned}
& 40 \text { Tart, "Un1ted States Relations with Western Europe," } \\
& \text { p. } 517 \text {. } \\
& 4 I_{\text {White, p. } 154 .}
\end{aligned}
$$


probable federal controls on the free enteprise syetem, a alsaster in Tart's opinion. White quotes him as saying that any future war ilight force "the nationalization of al Industry and all capltal and all labox" which could only mean an eventual "soctalist dictatorahlp."42 Even the preparation for war "was $11 k 01 \mathrm{y}$ to be almost as"jbad as war 1tself." 43 (Taft's anxlety in this area was shared by his colleague, Kennoth Wherry, who in addresalng the Senate once wondered rhetorlcally, "How long . . do you suppose America can escape becoming a garrison etate when annuel expenaltures are running at the rate of a hunared billion dollara?") 44 Such a view may sound strange in the light of his dodication to a strong alr and naval foroe, but taft actually felt that air and naval readiness would not be nearly as expensive as the malntenance of hundreds of infantry divisions. 45

Taft also insisted that much of his opposition to Truman's dosire to Increase American ground forces was basod on the manner in which the increase was to be carried out. He trolt that Iruman had to secure the approval of Congress before proceeding with any increase; to do otherwise would be tantamount to abbverting the Constitution. Taft referred

$$
\begin{aligned}
& 42_{\text {Ibid., p. } 150 .} \text { 43Ib1d., p. } 153 . \\
& 44 \mathrm{U} \text {. S., Congress1onal Record, p. } 328 . \\
& 45 \text { White, p. 153. In 1950-51 this may well have been }
\end{aligned}
$$
the case, although it $1 \mathrm{~s}$ almost Impossible to arrive at any cost comparison. 
to thls upon occseion as the "Pundamental 18Bue" in the great debate and at tacked executive agreements in forelgn policy because they threatened the liberties of the American people. 46 Whether 1t really was the "fundamental iseue" 18 open to serjous question; what mattered, however, wes that tactically Taft was able to hurt tho Adminietration more with this one charge than with other weapon in his armory. The 1dea of presidential usurpation of congressional power did not sit well wh his follow senators, and Taft know $1 t$. Even former Secretary of State Jeme日 Byrnes was forced to agreo, arguing, "If wo are to have a bl-partisan policy, the President should consult the leaders or the minority . . party before and not after basic deolsions or pollcy are made. Once deolsions are made, consultation 1s a sham. 47 Finally, for all his worryling about America beooming overextended in Europe, Taft was shoulder to shoulder w1th Knowland on "holding the IIne" in Asia. He became part of what White has aptly called "the polit1co-military oult that doveloped around General MacArthur." 48 Aglde from bestowing hosannas on MacArthur and h1s pol1c1es, the oult encouraged a strong sense of American national1sm, questioned the patriotiam and motives of certain Administration officials,

46U. S., Congressional Record, p. 61.

47 James F. Byrnes, "Firm Stand by a United People MeJ Prevent War," Vital Speeches, Fobruary 15, 1951, p. 269.

48 Wh1te, p. 167 . 
and, as has been shown, dented the notion of European defense being related to Amerlcan seourlty. Taft, White maintains," . Was not wholly comportablo in the cult aspect of the thing." 49 Perhaps not, but somehow he managed to hide his discomfort.

${ }^{49}$ Ib1d., p. 168. 


\section{NSC-68}

Much of the Administration's fear of the possibility the Sovlets would attack Western Europe was generated by the general Cold War atmosphere wh1 ch grew not $100 a b l y$ more frigid after 1948. Most authorities have fixed tro events in partioular--the detonation of the first soviet atomia bomb late in 1949 and the Communist attack on Bouth Korea In June of 1950-as the prime causes of th1s apprehension. Indeed, after the opening of the Korean War high off1c1ala. both in Washington and in the capitelo of Western Europe "seemed to be agreed that the soviets had shifted back from political means for aohleving their ambitions to milltary ones." The 1mpetus for providing additional American troops to NATO would therefore seem to date from this period. Actually, however, Administration eotion in thls regard began approximately $81 x$ months earlier. On January 30,1950 the wagldent authorized the National Becurity Counc1l to begln work on a seoret study (NSO-68) which would analyze the objeot1ves of the United States in peace and war during the ooming years. The study was completed in the

lRoger Hilsman, "NATO: The Developing Strategle Contoxt," NATO and American Security, @d. KIuss Knorr (Princoton: Princeton Universt trose, 1959), p. 18. 
spring of the same year and was to prove to be a mllestone of sorts in the shaping of American forelgn pollcy. While 1t has not yet been declassifled, the general reoommendation of NSC-68 are falris well known. It conoluded that Sorlet polley conslated of three major objectives which have been summerized as:

(1) to preserve and to: strengthen its position as the 1deological and power center of the Comenun1st world; (2) to extend and to consolidate that power by acquisition of new satellites; and (3) to oppose and to weaken any competing system of power that threatens Communist worla hegemony.

In light of these oonolusions, it seemed safe to predict that Sovlet milltary strength would continue to increase over that of the West unt1l "the economic rehabilitation of Western Europe and the full implementation of the NATO all1ance" were oarrled out. 3

The forecaste related in NSC-68 were not unanimousiy acoepted by all branches of the Administration, however. State Department orf1c1als were sharply divided over 1 t. The so-oalled "Kremlinologists" at State argued Moscow had no real desire to assume the role of an expansionist milltary power bent on world domination. Members of the Planning Staff; including Dean Acheson himself, argued that while this was Ine in theory, it must not detract from the

2Cabell Phillips, The Truman Presldency (New York: The Macmlilan Company, 1966), p. 306, olting Paul Y. Hammond, NSC-68: Prologue to Rearmament (New Yoris: Columb1a Un1versity Press, 1962), no p. no. given.

3 Itb1d., p. 307. 
fact that the Soviets would continue to probe for "weak spota". In the West and, once having found such frallties, would demana concessions. 4 It was neceseary, therefore, to eliminate the vulnerability of such areas by inoreasing the strength of military alliance systems such as NATO. Naturally, the view of the Acheson team prevalled.

St111, how valld were the v1ews and recommendations of NSC-688 Senator Taft, who knew nothing about the atudy, would surely have rejected it out of hand as a clumsy attempt to bolater the sagging NATO a.llance. Moreover, from the evidence so far available tt would seem probable that even those who were the most impressed with it vere not $\approx$ totally aseured of 1ta valldity. Inder the clrcumstances possibly the best defense of the report was penned by Dean Acheson almost twenty years later:

A decade and a half later a school of academic oriticism has concluded that we overreacted to Stalin, which in turn caused him to overreact to polloles of the Untted States. This may be true. Fortunately, perhaps, these authors were not called upon to anaiyze a situation in which the Un1ted States had not taken the action whioh it did tako. 5

Whatever the validity of the premises of the report, once they were accepted they had to be sold to the Congress and the publ10. Thls was preclsely what Acheson did in the late spring and early summer of 1950. Unfortunately, as he

4Dean Acheson, Present at the Creation (New York: W. W. Norton \& Company, I969), p. 753 .

5Ib1a. 
was later to admit, an "over-sell" was deemed necessary; consequentiy the nature of the soviet menace foll viotim to hyperbole. Agaln, Acheson himself expla1ned 1t best:

Qualification must give way to simplic1ty of statement, nicety and nuenoe to bluntness, almost brutal1ty, in carrying home a point. It is better to oarry the hearer or reader into the quadrant of one's thought than merely to make a no1se or to mislead him
utterly.

And so it came to pass that, in the Secretary's words, "If we made our pointe olearer than truth, we did not differ From most other eduoators and oould hardy do otherwise."7 As an "eaucator" Aoheson would prove to be no small success, even though some of his students turned out to be incorriglbie.

W1th the acceptance of NSC-68 in Administration circles and with Acheson's "over-sell" campalgn under way by late spring, obviously much of Washington's anxiety toward Sorlet Intentions in Europe had orystallized before the start of the Korean War. The dec1sion to augment NATO was olearly related directly to the 1indings of NSC-68. When the war In Korea 1gnited, it served only to relnforce a sundamental beller already hela by key Administration personnel: the forces of International Communism, directed by the Kremlin, were on the march.

$$
\begin{aligned}
& 6_{\text {Ib1a., p. }} 375 . \\
& \text { IIb1a. }
\end{aligned}
$$




\section{The Defense of Europe}

The Administration held a series of high level meet1ngs during the summer months to thrash out the exact nature the defense of Europe would take. Prodded by the Pentagon, Acheson and his advisers reached the concluston that German particlpation would be necessary if a successful defense of Europe were to be guaranteed. On the last day of July the Seoretary convinoed the President of this view. 8 The problem, however, now became doubly difflcult: not only would the American public have to be convinced that increased part1cipation in NATO was receseary, but it would also have to accept the feot that a former hated foe would bo needed in the alliance. This latter 18 sue would al so prove to be a sore point with the other alliance members. The Administration of course realized this, but the fear of a Soviot invasion was so strong that German involvement was considered eseential. According to Acheson: At the time... the danger to Europe seemed to us great and immediate, and these declsions were not being made in the unhurrled calm or an aoadem1c study." 9

These issues and others were brought to the attention of the other alliance members during a serles of meetings held in Now York beginning on September 15. To avold any unscheduled publio disclosure during these meetings,

$$
\text { 8. Ib1d., p. } 437 . \quad \text { 9Ib1d., p. } 440 .
$$


Prealdent Truman on September 9 first pubilcly announced America's intent to 1ncrease its forcos atationed in Western Europe. While not disolosing exaot 11gurea, the President let it be known that the number of additional troops needed would be "worked out in, close coordination" with other NATO members.

Conservative opposition to the announcement and the NATO meeting was largely blunted by the success of the Inchon Invasion in Korea. With the recapture of Seoul and the almost total anninilation of the North Korean armies, protestations in regard to European policy momentarily sank from slght. In fact, senatorial support for Truman's proposed troop inorease seemed to mount, at least among Admin1stration supporters. Senator Tom Connally, chalrman of the 1mportant Forelgn Relations Committee, remarked:

Despite the war in Korea and the tension throughout the Far East--let us never forget 1t--Europe 1s st1li the pirotal point. Continued Weakness in western Europe w1ll free the Sovlet Union for aggress1ve aotion everywhere. A strong Europe is a barrier, not only to soviet ambitions in the west, but to the Kremlin's freedom of action in the Midaie East and in the Far East as well.10

During the next two months the Naro question continued to simmer on the back burner while the Korean situation bubbled and eventually bolled over. Nevertheless, the derense of Europe and the question of American participation in that

10U. s., Congressional Record, 8lst Cong., 2nd Sess., XCVI, Part 2, 15,526 . 
defense could not be forgotten. As Acheson later put 1t:

The North Atlant1o Treaty, its organization, and Its military forces are recognition of the truth that no balanoe of power in Europe, or elsewhere, adequato to restrain Soviet power 18 possible unless the welght of the United States 18 put into the soales. Without assoclation with the United States, the European powers cannot prevent the leaders of the sovlet Union from having the1r way in Western Europo. Without American association with Western Europe, independent national ife in Eastern Europe cannot sevive. II

In order to pursue these ends, Acheson flew to Brussels in the midale of December. Once there he sought agreement for the appointment of an American as Supreme Commander of an integrated NATO force. Apter some discussion tho counoll dec1ded it "would appoint General Elsenhower as Supreme Commander of the 1ntegrated force and each government would put under his oommand its troops asalgned to the Integratod force."l2 Most observers felt that given Elsenhower'a background in World War II, the decision was milltarliy sound. Left unsald was the fact that since be vas an American, his appointment would ald in dampening ang conservative opposition to the NATO 1ssue that might develop within the United States.

Ironioally, however, whlle the secretary was adroltly maneuvering matters in Brussels, Herbert Hoover was busy delivering the opening cannonade of the great debate.

12Dean Acheson, Power and Diplomacy (Cambridge: Harvard UnIversity Presa, 1958), p. 84.

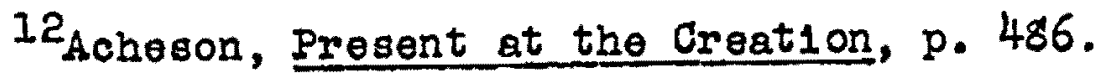


Rieturning to Washington on December 21, Acheson Was aghast when be heard abqut Hoover'g speech: "The stench of spiritless defeat, of death of high hopes and broad purposes, given off by these otatements deeply shocked me. It took a day of talking with my associates for the s1tuation to sink 1n."I3 Apparently the exact nature of the Hoover speech had caught the whole Administration off guard. On December 19, only two days earlier, President Truman had indlcated little concern over the strength of his domestio opposition:

Q. Mr. President, in Ine th what you have been telling us about forelgn policy, a number of writers believe that there is a--as they put $1 \mathrm{t}--a$ wave of isolationism rising in the United Stater. Do you reel that condition to exist?

THE PRESIDENT. I don't think there 18 any wave of 1 solation $1 \mathrm{sm}$, put side of the Chicago Tribune and those papers.14

Owing to the reverberations of the Hoover speech, the Administration began to have second thoughts over the possible influence of the new isolationists. On December 22 Acheson called hls own news conference and sharply rebutted polnt by point Hoover's remarks. He ended by calling on the American people to reject "any polfcy of sitting quivering In a storm cellar walting for whatever fate others may wiob

\section{Ib1d., p. 489 .}

14U. S., President, "The President's News Conference of December i9, 1950," Públic Papers of the Presidents of the United States: Harry 5 . Truman (Washington: United States Government Printing Offico, 1965), p. 752. 
to prepare for us."15. As the news conference concluded, it was clear to most onlookers the Adminlstration was now qully cognizant of the danger posed to the nation's forelgn pollcy by the Hoover-Taft segment of the Republican Party and wa prepared to engage it in verbal battle. Just three days before, the President had stated he could see no "wave or 1solation1sm" washing over the country. Now Acheson had asserted that neither was the Administration going to allow one to swell up.

So matters rested for the rematining two weeks of the old year as both camps broke for the respite afforded by the holldays. Yet it seemed a foregone conclusion that with the coming of the new year the great debate was going to take up a lot or everyone's time.

\section{The Conservatives Attack}

The attack on the Administration's forelgn pollcy was launched anew in a long speech made by Robert Taft on the Floor of the Senate on January 5, 1951, just three days before the President was scheduled to deliver his annual State of the Union adress. Taft's remarks were noteworthy for thelr scattergun effect: they hit just about every target that had ever outraged the American Right. In some respects they also conveyed a sense of Irustration, of some

15Dean Acheson, "Un1ted Aotion for the Defense of a Free World," The Department of State Bulletin, January 1, 1951, p. 6 . 
desperate grandstand play needed to gain the public's attention and win its support of forelgn pollcy issues.

Beginning with Korea, which in January of 1950 seemed the epltome of hopeleseness, Taft lashed out at America's role in the world. Korea afforded Taft an excellent examplo with which to attaok the Administration because his orm views on the war were always so amblguous. On the one hand he demanded a policy that would insure "total v1ctory" over Communism in Asia. Yet on the other he opposed the "needless slaught er of Amerioan boys," even if such opposition meant the total evacuation of American troops from the area. Regardless of what the Adminlatration did, then, the Korean War became a convenient political whlpsaw whlch Taft and his rellow dissidents used to bludgeon 1 . On occasion, as in his speech of January 5, this strategy took some ourlous trists. Taft proposed that the United States had been duped by the Soviets into getting involved in the war in the first place. This they had accomplished by slyly inveiging the Adminiatration into initiating and helping to pass the United Nations resolution which authorized a military response to North Korea's aggression, a resolution the Soviots could not veto because they were boycotting the security Counoll at the time. However, since the Chinese entered the war it had become 1mpossible to pass a similar resolution against them because the Soviets were once again partic1pating in the Security Council. wo Taft the lesson was 
clear: proper Unitod Nat1ons military action againat China (the bombing of Chinese bases and supply I1nes, for instance) could not be brought to bear because of this trickery. The Sov1ets at 11rst had purposely stayed away from the Security Couno1l meetings in order to "Buck" the United States 1nto the war, and then they had reolaimed the1r seat in order to Insure the Chinese an opportunity to engage America in an endiess and apparentiy stalemated ground war. Taft could only sady surm1se: "We were sucked into the Korean War, as a representative of the United Nations, by a delusion as to a power whloh never has existed under the Charter."16 As to the future, he would not hesitate a guess but offered the suggestion that if worst came to worst, it would be "far better to fall back to a defensible position In Japan and Formosa than to mainta1n a Korean position whioh would surely be indefonsible in any third vorld war. 17

Taft's wllingness to "fall baok" to Japan and Formosa was again indicative of his strong trust in air and sea power. American alrcraft and naval vessels would be able to defend these 18 lands from any foe. H1s reasoning for so thinking was often grounded, as hts biographer W1lliam S. White has already shown, In questionable historloal

16U. S., Congressional Reoord, 82d Cong., Ist Sess., XoVII, Part I, 57 .

17 Ib1d., p. 58 . 
analogies:

Our position is not greatly unlike that of Great Britain, which dominated much of the world for a perlod of 200 years, and brought about the balance of peace of the last half of the nineteenth century. The British had control of the seas and met every ohallenge to that control. There was no question of alr power. They seldom committed any considerable number of Britiah land troops to continental warfare, and when they did so they were by no means successful.

It was the sea power of Britain which gave Britain a powerful influence on the Continent of Europe 1tseif. It seems to me that by reasonable alliance with Britain, France, Holland, Austral1a, and Canada the control of sea and alr can establish a power wh1ch never can be challenged by Russia and wh1ch can protect Europe as it has been protected now for. 5 years through foar of what sea and air power can accomplish against Russta. 18

Even with such a firm belief in the might of sea and air power, Taft made it plain he still folt there was a need for a professional army. Using the opportunity to switoh from the Far East to Europe, he did "not object to committing some limited number of American divisions" to Europe provided the Europeans themeelves contributed a larger amount to NATO defense. He further cautioned that such a program "never ought to be a key point in our overall m111tary strategy."19 St1Il, whatever his intentions, his statement signifying that some American troops in Europe would be permise1ble was to prove to be a source of alfficulty to him in the coming weeks. The importance of his remark had not been loot on tho Administration.

${ }^{18}$ Ibia., , p. 58. 19 Ib1a., p. 60. 
Taft's apparent ungwerving falth in a1r power was jolted midway through his speeoh when a senator Irlendly to the Administration's position challenged some of his assumptions. Senator Paul Douglas rose to inquire why, if air power were such a panacea, had it not turned the trick in Korea where the United States enjoyed complete alr dominance. The Chinese were continuing to push back United Nations' forces, and American air power was seemingly incapable of stopping them. Taft was frankly forced to admit, for the first time, that bombing alone was not going to stop an army. To which Douglas asked:

Does it not follow from the Senator's statement that, 19 continental Europe does not bulla up a sufilcient army to cheok the communtsts on the ground our threat of bombing from the air will certainly not stop the Communist armies if they wish to move into Europe?

MR. TAFT. Once war is deolared it w1ll not stop the Communist arides, no.

MR. DOUGLAS. And Will not the Communist armies therefore sweep through completely to the English Channel?

MR. TART. Does the Senator think there would be any difference if we have 10 American divisions there?

MR. DOUGLAS. That 1s something else.

MR. TAFT. It is not something else again. It is exactiy the question the Senator 18 asking. I am saying that the commitment of Amerlcan troops vill not aubstantially change that situation. 20

In this short encounter lay the rationale for all the verblage of both oamps concerning the merits of air power. Unfortunately; three months were to pass before most of the partlclpant sully realized this fact.

20 Ib1d., p. 62. 
The bellef in the invinotbility of alr power was not an ersy one to at spel among cortaln Republicens. The Republican minority leader, Kenneth Whorry, held to the opinion throughout the debate that alr power was tho "dec1sive" weapon in World War II and therefore would be in World War III also. He conceded that $1 f$ war came to Europe, the Unfted States would be unable to stop 1t, but the "Russian horde" would soon become "powerless" because Amerlcan bombIng would cripple Russlan Industry and agriculture at home. Reasoned the Nebraskan:

- There 18 nothing unique about trading space while getting off knock-out punches by a1r and sea. It 18 not pleagant to contemplate Europeans taking another occupation, temporary though it may be, but there w1ll be many more Europes left, and more of their industries still standing, in that circumstance, than if we wage ground war, with another inferno of guns and tanks and bombs consuming Europe. It is a case of the lesser of two ev11s. 21

In other words, not only would massive bombling of the Sorlet Union bring about the end of Red aggression, it would also save Europe from the physical destruction that would result from the clashing of large ground armies. To engage Amerloan troops in such an "inferno" in Wherry's view would be a "Pool1sh venture."

Taft, while agreeing with Wherry, wondered $1 f$ the Inferno could not be postponed altogether by not antagonizing the soviets in the first place. This could be quite a1mply acoomplished by not inoreasing the size of NATO 2IIn1d., p. 328. 
forces. Otherwise, asserted Taft, "the building up of a great army surrounding Russia from Norway to Turkey and Iran might produce a fear of the invasion of Rusala or sone of the satell1te countries regarded by Russia as essential to the defense of Mosoow."22 Understandably, the Soviets saw the situation in largely the same light and indicated that Taft's eveluation of any future ground war was a correot one. The correlation between Taft's viow and the Kremlin's was duly noted by the Administration, and during the midale of the debate the State Department reprinted-no doubt gleeIully-a Tass report which observed:

Even such an experienced reactionary as the American Senator Taft war recently forced to admit that the plans which are belng hatched by the American aggressors for a war with Russia on the European Continent by land forces are doomed to fallure and that an invasion of such a kind would prove $t_{B}$ be impossible as Napoleon and Hitler discovered. 23

Taking a somewhat different tack, other conservatives argued that Europe must learn to stand alone. Senator Willian E. Jenner offered a sample diagnosis: Europe would depend on the United States as a "orutch" as long as the "crutch" remalned avallable. A limping Europe lacked the "heart" to:defend itself. 24 Earlier, Senator Edwin 0. Johnson had reported to h1s colleagues that from what he had witnessed firet hand and had been able to plece together

22. Robert A. Taft, A Foreign Policy for Americang (Garden City: Doubleday \& Company, Inc., 1951), p. 1I3. $1951, \mathrm{p} \cdot \frac{\text { The }}{260}$. 23The Department of State Bulletin, February 12 , 24 U. S., Congressional Record, 82d Cong., lst Sess., XOVII, Part $2, \frac{\text {, }}{2601 .}$ 
from others, the people of Western Europe did not think war wes Imminent and consequently were "very calm and complecent about the whole thing." This was so desplte the fact that France and Italy were "teeming with combun1sm." Furthermore, 1t hardy made good sense to send the American army to countries such as Germany since 1t was "the most pac1fist country in the world. "25

Pacifiet or not, for some Administration opponents NATO would be 1mpotent unless the participation of West Germany was insured. Senator Joseph MoCarthy went one step further and asserted that it did not make any difference whether the United States sent one or ten or twenty divisions to Europe; the entire region would be lost "without the manpower of Spain and Westers Germany." Any plan that did not incluae both of these countries would constitute a "phony defense." 26

While most of the spotlight of publicity was concentrated on the senate during the great debate, the Houge occasionaliy did enter the fracas. Midway through February, House minorsty leader Joseph Martin reluctantly conceded that America should provide equipment "and possibly some of the manpower" necessary for the defense of Western Europe. Still, he emphasized that the "rocal point" of America's troubles was As1a, not Europe. Martin warned he would use every resource at hlis command to counteract any Administration

$$
\text { 25Ib1a:, Part 1, p. 497. 26Ib1a., Part 2, o. } 2397 .
$$


strategJ wh1ch 1gnored Asla. 27 Two days later, 118 of h1s fellow Republicans went even further. Offering something called a "Decleration of Pollcy," the group demanded "that the United States concentrate 1ts m111tary efforts on defendIng the Western Hemlsphere" and cease supplying ald of any kind to Western Europe unless that area Indicated a willingness to carry "1ts fulf share of the burden." 28 Juet preo1 bely what a "full share of the burden" constituted remalned cloaked in ambigulty. A definition was hardly necessary, however, since the actual purpose of the manfiesto was to drum up publicity and pressure for the Taft position in Iight of the fact that 'Senate hearings on the lague were slated to commence the following day.

\section{Trumen's Response}

While Taft and his supporters continued to attack Amerioa's defenolve posture, the Administration was far from Inact1ve. On January 8,1950 President Truman del1vered h1s annual State of the Union address and left little doubt as to where the Administration stood in regard to the troopsto-Europe 1ssue. Pointing out that NATO constituted the "heart" or America's defense, he declared that it was also "the bas1s for defense of the whole free world." The all1ance could not be abandoned, for if it were, it would mean

27 The Now York T1mes, February 13, 2951, p. 24. 28Ib1d., February 15, 1951, p. 1. 
the "loss of the largest workshop in the world. . . Strategleally, economically, and morally the defense or Europe 1s part of our own defense." 29 The speech was generally applauded both at home and abroad. The Brit1sh soemed part1oularly 1mpressed and The Times commented editorlally:

No democratic leader has set out so simply before the duty which now falls upon each and upon all. The connexion between the United States and Europe is a partnershtp in self-help and self-delence. There is no question here of paymaster and pensioners or satellites. Each has to give, for its own peacerul survival and progress, its due share, accoraing to ita resources, to the grand design of successfully deterring attack, for the first time in history, by the prompt and sufflclent show of peaceful strength. The safety of Amerlca and that of Europe, as the President gald are one. The President has set a

Determined not to be overshadowed by Truman's address, the Republican dissidents sought publicity of their ow on the very day of his speech. Senator Wherry counterattacked by introducing a resolution that would attempt to stymle the President's troop proposal: "Resolved, That it 18 the sense of the Senate that no ground foroes of the United States should be assigned to duty in the European areasfor the purposes of the North Atlantio Treaty pending the formulation ' of a polloy with respect thereto by the Congress. "3l

29 Fred L. Israel (ed.), The State of the Union Messages of the Presidents (New York: Chelsea House, 1966), III, 2979 .

30 The T1me日 (London), January 9, 1951, p. 5.

31. S., Congressional Record, sand Cong., ist Sess., XCVII, Part i; 94. 
any future attack, but because they would act as "the vital increment which would to a great extent create the wilingness of Western Europeans to enlarge their armies." Further, if the United Stator ald not inoreaso its foroes it would probably cause the European powers to do $11 k$ kew se and could well lead them to "throw in the sponge." 33

Senator Estes Kefauver agreed with Douglas and rose to add that in his view the Soviet Union was "bent on world conquest," and its weapons were "propaganda and brute Porce:"34 A Republican, Senator Wayne Morse, concurred:

The danger that the Soviet Communists will resort to war to advance their imperialistic aim is of the utmost gravity and reality. There is no doubt whatsoever that Communist 1mperialism $1 \mathrm{~s}$ out to spread over the world--over Europe and Asia by indirect aggression if possible, ultimately, I think, by war 11 necessary. 35

Morse's statement was clearly meant to be in support of the Administration's position. Nor as a Republican was he alone in taking such a stance. Taft was simply unable to convince a number of fellow Republicans that Truman had misread the 1mportance of the European defense pleture. Such lack of political cohesion did much to explain why Taft was ultimately unable to win the great debate.

One of Taft's toughest antagonists turned out to be Republican Governor Thomas Dewey of New York. In early February Dewey made it plain he supported a joint alr-seaground defense of Europe, end that the deployment of such

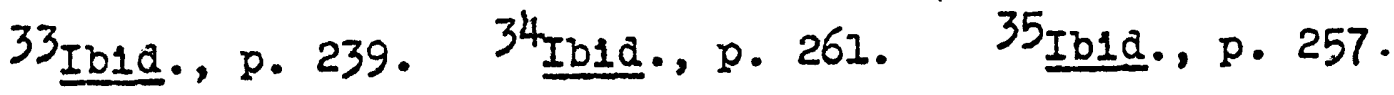


forces would require no approval from Congress. Troop deployment, argued the Governor in what had to be a clear slap at Taft, "was a job for experts and not for pol1t1clens."36 The following evening (February 12) Dewey went even further in hls support for NATO. He was quoted a adrooating the alliance "be extended along the Mediterranean Sea and beyond 1ts eastern shores as a means of reducing the land area upon whlch Russia might have designis for aggress1on." 37 In other words, Dewey was seeiring the inclusion of Greece and Turkey into NATO:

Dewey's atatements were among the strongest uttered by one Republican againgt another durlng the course of the debate. St1ll, his remarks were not indicat1ve of a simple two-way split in the party. An analysis by Willian $S$. Wh1te near the conclusion of the debate in late March found the Republicans. had hopelessly splintered into no less than four factions, with some overlap occurring on many of the points. 38 The pleture emerging, then, was that of Taft unable to rally the majorlty of his own party behind him w1th the ranks of the Democrats remaining almost solld. Many or the votes that Taft had hoped to garner were lost during the first half of February when the Administration made a determined effort to squelch his arguments once

36 The New York T1mos, February 12, 1951, p. 1.

37 Ib1d., February 13, 1951, p. 1.

38 Ib1d., March 31, 1951, p. 4. 
and for all. The offensive began on a low key when General Elsenhower returnea from Europe and reported to a joint session of Congress h1s observations of European defenee. The General atressed oquipment, not men. He pleaded that Western Europe be supplied w1th the latest military haraware avaliable to insure Europe's soldiers would not be outgunned by their Sorlet counterparts. Almost in passing he added: "I belleve that the transfer of certaln of our units should be in direct ratio to what Europe 18 do1ng so that wo know that we are all golng forward together, and no one 18 susplelous of the other. "3\%

The return of Elsenhower was quickly folloked by a series of joint hearings held by the Senato Forelgn Relations and Armed Services Committeed in which key military and forelgn affacs personnel testifled. Secretary of Defense George $C$. Marshall opened by revealing for the f1rst time on February 15 exactig how many adational troops the Administration was proposing to send to Europe:

We already have there, on occupation duty, about two divisions of ground forces. Our plans, based on the reoommenation of the Jolnt Chiers of Staff, therefore contemplate sending four edditional divisions to Europe.

While this number aoes not appear to represent in pure lighting power a large contribution to the immediate defensive strength of Western Europe, it does represent a amall Army unit of high efficienoy and, we believe, a tremendous morale contribution

39. S., Congressional Record, 82d Cong. lat Sess., xcVII, Part 1, 875. 

to the effectiveness 4 and build-up of the projected
ground forces. . . $4 \delta$

What Marshall ald not say was that such a relat1 small force would unioubtedly catoh the Taft forces unawaros, whioh 1t d1d. Taft and his supporters had been expecting Marshall to propose a far larger force than he did, possibly something in the neigtborhood of ten divisions. When he asserted only four would be needed for the time being, he in effect sprang a subtle trap on the Taft forces: only a week before Taft himself had confessed he. was prepared to allow "a lew more d171810ns" to Europo whthout debate. Spec1fically, on February 8 Taft had sald: "W1th regard to the sending of troops to Europe without any commitment no doubt the President has power to send div1slons to oocupy Germany, whlch 1 it 18 our obligation to polloe and defend. But 1 t can hardiy be clalmed that this power would justify sending more than two or three additional divisions." 41 The Adminlstration simply 1ncreased Taft's three division 1 gure by one and then took the position 1t was really sending about the same number he was wliling to allow anyway. With this one apt maneurer tho Administration, and Marshall and Acheson in particular, had clearly outflanked Taft. Years later Acheson confesied:

\footnotetext{
40 The Department of State Bulletin, February 26, 1951, p. 329 .

4IU. S., Congregsional Record, p. 1119.
} 
W1th the President's consent, General Marshall revealed in public testimony what the Adminiatration had in mind. It was four more divisions, making a total of 81x. Ne1ther he nor General Bradley would bo led into making that number a ceiling. It was, at the time, the meeting point of need and convenience; that point could in the future move up or down. They refused to epeculate. Senator Tart was neatiy caught. "A $f e w "$ was more than two, three enyway, which reduced the great strateglo issue, as had been etated by President Hoover--of holding the oceans by a1r and sea power versus involvenent on land--to an argument over one division to Europe. 42

Acheson went on to relate that once Taft realized "his predicament," he attempted to overoome 1t by ahifting the 18sue, at stake in the dobate. His "new position," claimed Acheson, was one or challenging the Administration'a right to send any number of diviaione without the approvel of Congress. Here Acheson's rellability must be called to question. Taft's "new position" was not "new" at all; it was one of the many 1 saues he had linked to the debate over troops right along. It may well have been that after Acheson and Marahall sprang their trap Taft was forced to shift gears; but he certainly did not bring up issues that he had not already introduced. The question or Congressional approval was one that Taft had harped on since the very beginning of the debate, and he would continue to argue this point until almost the very last.

In any event, the Administration continued to pross its case hard. The very day after Marahall's testimony, the.

42Dean Acheson, Present at the Creat1on (New York: W. W. Norton \& Company, 1969), p. 495 . 
Chalrman of the Jo1nt Chlers of Staff, General Omar Bradley, volced the view that additional Amerioan troope were necessary to reassure the Europeans the United Statea Intended to help them defend theme日lves. Furthormore, Bradiey concluded, "this increase in collective military strength is needed as a deterrent to the aggressive intentions of soviot Rus81a." 43

Bradley's remarks were followed within a few days by statements from the country's three highest ranking alr force, navy, and army offlcers. All three of them agreed with the Administration's proposal and all concurred that alr and sea power could not alone be counted on to save Europe from Russian occupation. 44 Senator Wherry, who had been invited to sit in on the testimony although he was not a member of elther partiolpating commlttee, tried to press the Army Chief of Staff, General J. Lawton Collins, into admitting it would be better to rely on "pulverizing" the Sovleta w1th atomic bombs than on committing American troope to Europe. General Collins "perslstently rejeoted such a theory, saying to Senator Wherry that no amount of bombing of the Russians could keep them from occupying Burope and that bombing alone could never beat them." 45

43 The Depertment of State Bulletin, February 26, 1951, p. 331.

44 The New York T1mes, February 20, 1951, p. 1. 45 Ib1d., p. 5. 
Administration critios regained some hope when the commanding general of the st. ategic Air Command, General Curtis E. LeMay, was called to appear. LeMay testifled that whlle' he agreed with the Prestdent's declsion to send four more divisions, he also belleved thet all of the forces contemplated for Europo's defense at that time would:'not be adequate to stop a Russian invasion. In the general's mind these divisions would represent a "holding force," while the "main blow" would have to come from atrategle bombing. 46 LeMay, then, of all the milltary officers called to testify before the two committees, was the only one who even came close to supporting the Taft thes1s. But even he did not advanoe the possiblilty that any future war in Europe could be won by alr and sea power alone.

After questioning and listening to the various generala, Senator therry. still was not satiafied. He complained from the Senate floor late. In March: "The dominant v010os in the Pentagon, General Marshall, General Bradiey, and General Collins, all ground offloers by training, have thelr eyes glued to the ground, when they should waire up to the aeronautical facts of life. Our air power is the chief deterrent to World War III." 4 I

Other senators were even more upset by the military testimony. They viewed the committee hearings as a sham, 46 Ib1d., February 22, 1951, p. 1. 47u. S., Congresgional Record, Part 3, p. 2907. 
feeling the generals were bound to say whatever they were told to say. Of Eisenhower's 1nspection and faot-finding trip to Europe, for instance, Senator George W. Malone blustered:

The purpose [or the trip] was obviously to secure support for a decision which was fully decided upon beforehand. I do not belleve that anyone 1s nalve enough to think a week or two jumping from one. European capital to another, could accompliah any purpose other than that of propaganda for the preconoelved decision of the state Departiment to 48 end our boys to make up a Maginot I1ne in Europe.

Malone, Wherry, and a lew others were making a point, but it was a point born of frustration rather than reality. It was of course diffecult to know precisely how much of the milltary testimony reflected the actual thought $\mathrm{s}$ of the generals and how much of 1t had been "preconcalved" by the Adm1nistration. What Malone and Wherry refused to admit, however, was that it was the duty of these officers to follow the dictates of their Commander-In-Ch1ef; if they had truly opposed his military and political declsions, they should have resigned.

\section{The Acheson Test1mony}

The h1gh water mark of testimony favorable to the Administration's position undoubtedly occurred on February 16 when Dean Acheson read a long prepared statement in wh1ch he carefully outlined the need for aditional troops in Europe. It was to become the Administration's definitive 48 I I 1 a. , Part I, p. 952. 
statement on the 1 ssire.

Acheson's remarks wore awalted wh greatest ant1c1pation by his senatorial foes. Much of this was due to the symbollc quality assoclated with him; whether he wanted to be or not, he had become in the minds of many the "onler architect" of the Truman forelgn policy. H1s enemles were also fond of recalling that on a similar occasion in 1949 , Acheson had committed one of the major blunders of his career. When agked at that time by Senator Hickeniooper, in connection with the original ratification of the NATO pact, if the United States would ever bo expocted to send substantial numbers' of troops to Europe "as a more or 1088 permanent contribution," Aoheson replied: "The answer to that question, Senator, is a clear and absolute 'No.,"49 This unfortunate response was increasingly to haunt him for the next two years. His, opponents would not let him lorget 1 t. He was later to candldly admit: "Even as a short-range prediction this answer was deplorably wrong. It was almost oqually stupia. "50 Now once again he was to test1fy regardIng NATO, and naturally his opponents were hopeful of another error in judgment, one that would prove fatal to both NATO and the Secretary of State. But this time he was to sisappoint them.

${ }^{49}$ U. S., Congress, Senate, Comm1ttee on Forelgn Relations, Hearings, on the North Atlant1c Treaty, 81 st Cong., lot Sess., p. 4 . 50 Acheson, p. 285 . 
Basically, Acheson framed his ilne of attack with the same reasoning the generals had employed before the same committees. He argued the United States had to depend upon a "balanced collective force." And while he frankly conceded that for tho present Amerioa enjoyed a "bubstantial lead in alr power and in atomic weapons," this advantage would gradually be lost over a perlod of years. It was therefore important to continue to deter aggresion after this advantage had been diminished. The only way to do so would be with a balanced force that had as much military muscle on the ground as on the sea and in the air. He went on to note that critics had labeled such a program as 1lluslonary because 1ts foroes simply could not be made large enough to offset those of the Soviet Union. The trouble with such reasoning, he asserted, was that 1 t convenlently separated European defense from the rest of the American defense network. European derense forces could not be considered in 1solation, as a weapon all by themselves; rather, they had to be seen as a "vital adjunot to the other deterrent forces avallable." 51 summing up, he renewod this plea:

In the event of an attaok the avallability of defense forces in Europe would glve us time that we would vitally need to bring our other forces into operation. In the meantime these derense forces would obl1ge the aggressor to use up his avallable resources, whlle his home sources of supply were belng bombed. These forces would also deny him

51 Dean Aoheson, "The Joint Defense of Western Europe" The Department of State Bulletin, February $26,1951, p .324$. 
access to the Industrial, human, and other resources of Europe. These are the resources that balance the scales of power. The ge are the forces that would prevent Europe, in the event of an attack, Irom having to go through another occupation and ilberation. 52

Acheson's presentation was on the whole a masterful performance, one that left his critlcs with little new to assault. Of course they could not and ald not accept his arguments, but ne1ther could they flnd anything weak enough In them to win over those senators who had been up to that time noncomittal on the troop 1ssue. Clearly, the secretary's testimony was a tour de force, an accomplishment which effectively sealed the fate of the entire debate. In retrospect, however, hís case was not without flaws.

Early in his remarks, for example, Acheson cautioned his audience by suggestiong that the danger confronting Western Europe was not just the obvious one of overt mil1tars aggression. There were also several other threats:

- - conquest by default, by pressure, by persuasion, by subversion, by "neutral1sm," by ali. the paraphernalia of indrect aggresgion which the Communist movement has used. 53

If the United States engaged in a sort of one dimenslonal strategy which ignored these other factors, then it could only be expected that such a policy would drive "our friends In Europe into a mood of non-resistance, a mood of ineutral$1 \mathrm{gm}, 1$ which is for them and for all of us a short cut to sulc1de."54、Acheson's successor, John Foster Dulles, once

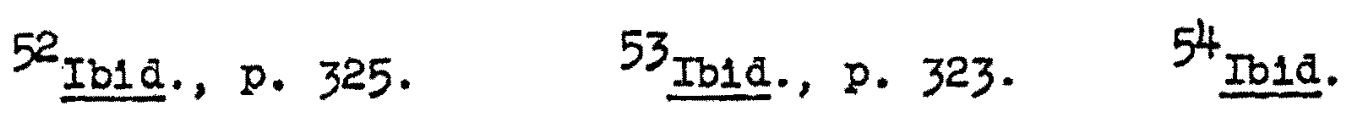


referred to neutralism as being "Immoral" and was subjected to such a fusiliade of verbal brickbats that he never troubled to bloach the subject whth such terminology again. Iet, oddly, no one thought to challenge Acheson's groundlegs assumption. Presumably, even his opponents thought sulcide to be an accuratio prediction of the fats of neutral countries.

The possibli1ty that Europe would somehow be "gubverted" by internal Communist movements was also extremely remote in 1951, desplte what Acheson said. Indeed, within one month of his statement, his own Department of State had 1sgued statistics which cast serious doubt on such a possibility. After explaining to the reader that Moscow was "losing the battle to take over Western Europe by boring from within," an officlal communique stated that since 1946 Communist party membership had declined by 34 per cent in Austria, 30 per cent in France, 31 per cent in Italy, 65 per cent in Norway, 34 per cent in Western Germany, and 34 per cent in the United Kingdom. 55 But once again, in so far as Is known, not one of the Administration's conservative opponents: attempted to make an 1ssue of this apparent discrepancy.

55 "Commun1sm on the Wane in Western Europe," The Department of State Bulletin, Warch 12, 1951, p. 407. 


\section{Senate Resolution 92}

After the Senate Forelgn Relations and Armed Forces Committees had sat through most of the month of Febmary listening to and questioning Dean Acheson, George Marshall and $a$.bevy of generals, it became obvious most senatorg had made up thelr minds in favor of the Adminiotration's proposal. Indeed, the decision of the Committees was unanimous. By a vote of 23 to 0 they eleoted to leave the government "Iree to commit whatever forces were 'necessary and appropriatel" to uphold Amerioa's fair share of the NATO effort. 56 Truman had overpowered Taft and h1s allies and it now semed only a matter of time before he would go ahead end order the four aditional divisions to Europe. The dobate continued from the floor of the Senato for approximately a month, but as the days drifted by it became increasIngly obvious that few people wore really paying attention. The whole Taft-Wherry-Knowland effort seemed to disitegrate after the hearings concluded.

A pollt1cal autopsy of the debate quickly reveals why. At best Taft was able to count onjonly about one-third of the Senate to see the matter his wey. Not all of the rematn1ng two-thirda were necessarily on the s1de of the Administration, but neither was Taft able to win then over. The b1g factor was his inability to Iind any professionel

56.The New York Times, March 9, 1951, p. 1. 
m1litary men who would champlon his views. (MacArthur of course was at1ll in Kor $\theta a$, but he took no direot part in the great debate.) W1thout some m111tary support, Taft's pos1tion became untenable. As one observer has summarized:

Faced with executive unanimity and the staunch defense of the Administration's position by three of the nation's four most popular soldiers (Marshall, Elsenhower, Bradley), the opposition senators falled to define any clear alternatives to the Administration's action, wuch less to influenos or to reverse the character of that action. 5 ?

The flnal act of the great debate occurred on April 4 when the Senate; by a vote of 69 to 21, approved Senate Resolution 99. The resolution had first squeaked through two days earlier by the thin margin of 46 to 44 , but a coalition reported to be composed of Republicans and Southern Democrats forced the Senate to reconsider and to adopt a declaration submitted by Senator John L. McCleIlan of Arkansas. 58 The McClelian amendment, which turned out to be a stipulation calling upon the President to seek congresslonal approval for any further troop 1ncreases to Europe, was adopted by 49 to 43 . It was then attached to the fuIl resolution which passed by a final tally of some forty-e1ght votes. The resolution which thus emerged was the ultimate outgrowth of the one Senator Wherry had elrat introduced in January. It had, howover, beoome so amended over the months

57:Samuel $P$. Hunt1ngton, The Common Defense (New York: Columbia Univeraity Press, 196IT, pp. 324-325.

$58_{\text {The New York Times, April 3, 1951, p. } 1 .}$ 
that Wherry himself could no longer support 1t. On the other hand, Taft and Knowland viewed it as the best possiblo under the clrcumstances and voted for 1ts adoption. Others may have been puzzled over just what it did, but roted for It anyway. As with most measures that eventually work their way through the leglslative process, Resolution 99 came through as a compromise, one, as Dean Acheson later remarked, that "had in it a present for everybody:" Acheson's comment would seem to explain the resolution's final lopsided acceptance.

The resolution, being just exactly that, volced the sense of the Senate and had absolutely no legislative power. It approved the selection of General Elsenhower as the Commander of $\mathrm{NATO}$; it noted the exiatence of a threat to the securlty of the United States and 1ts NATO partners which necessitated complting units of "armed Forces as may be necessary and proper" but warned that not more than four divisions should be deployed "without further Congressional approval"; It noted the President should consult with the Secretary of Defense, the Jolnt Chiefs, and appropriate congressional committees before sending troops abroad; it agked the Jolnt Chiefs to ascertain if other NATO members were providing their contribution; it requested semlannual reports on the 1mplementation of the NATO treaty; and 1t asked that consideration be given for the inclusion of Hest 
Germany and Spain into the pact. 59

As there was no actual legislation involved, the Administration could have ignored the resolution entirely had it so desired. Instead, it wisely chose to accept it as a victory. The President isoued a statement which said in part:

The clear endorsement of the appointment of General Elsenhower and the plans to assign troops to his command shows that there has never been any real question but that this country would do its part in helping to create an integrated European defense force.60

In an editorial on the same day, The New York Times optim1aticaliy reported: "Eren with its amenaments... the adoption of the resolution should provide Western Europe with new confldence to go full steam ahead with the defense programs agreod upon." $6 I$ The T1mes' editors apparently had not boen doing their homework; Western Europo by this date was paying 11ttle attention to the outcome of the great debate, so involved had it become with its own difficulties over NATO. France, clinging to bitter memories fostered by World War II, remained wary over the role West Germany was to play in the alliance. Other members, Great Britain in partioular, had become disturbed over the inoreased costs NATO would mean. By the spring of 1951, regardess of tho

59 The resolution in its entirety may be found in the Append1x.

60The Department of State Bulletin, April 16, 1951, p. 637 .

6I"Troops for Europe," The New York Times, April 5, 1951, p. 28. 
outcome of the great acbate, Europe indicated 11ttle 11ke11hood of proceeding at "full steam ahead." It soon became olear that the trensformation of NATO into any meaningful milltary alliance was to bo an agonizingly slow process.

In the United:States, too, another matter soon diverted attention. Within a week of the passage of Resolution 99 the entire affalr was momentarily forgotten following the President's removal of General MacArthur Irom hia command. Unofflcially, the great debate was now over, but the fresh controversy which arose from MacArthur's dismissal Indicated some of the disputed iseues could not be resolved by the passage of a congressional resolution. 
CEAPTER IV

\section{AN APPRAISAL}

The great debate, then, did not really conolude with the passage of Resolution 99 on April 4. To be sure, the question whether four additional divialons would be sent to Europe was settlea, but the question whether Europe or Asia had Ilrst priority in Amerloa's defenelve strategy continued to be hotly dobated. With Truman's dismissal of MacArthur the whole affair was opened anow, more voclferously than ever. The resulting uproar was to last well into the summer of 1951 and the consequences of this hect1o period were to haunt the Truman Administration unt1l its last days in office. Yet the debate itself had grappled with, or created, a number of important issues, some of which were to help formulate American forelgn polloy for the next fifteen years. The debate's effect on the immediate ruture of the Republican and Democratic parties was also notable.

\section{The Question of the Sotiet Threat}

During the debate much of what Taft, Hoover, Knowland, o and others protested concerned the question of the need for adational troops in Europo. It will be recalled that Tart In particular argued that ho could find no sign the Soviets were preparing any overt milltary action against Western Europe. In his mind the threat which existed was in the Far 
East. Clearly, the results of the debate show the Administration won the argument, at least in so far a a majority of the Senate was concemed. Yet what is not olear, even after a hiatus of some nineteen years, 1s whether 1to evaluation was sound. Was there, in fact, any serious possib1lity of a Soviet invasion of Western Europe during the early $1950^{\prime} \mathrm{s}$ ?

The only ract that can be stated for certain 18 that there was a climato of fear and suspicion prevalent in the United states. This in it self was probably enough to cause the Administration to assume an attack would occur. The Iindings of the National Security Counc1?, as relayed in its paper NSO-68, were undoubtedly an 1mportant contributing factor. Jnfortunately, this entlre paper still remains classifled, even though less than one per cent of 1t originated from classified sources. ${ }^{1}$. Accoralng to Dean Acheson, this information put the need for a atronger alliance "beyond argument." At best, then, the hard evidence for the necessity of sending American fordes to Europe was based upon a super secret portion of NSC-68. Unt1l this information 18 deolasolfled, it seems doubtrul any final conclusion can be reached in regard to the posa1b1lity of a Sorlet atteck during this period.

IDean Acheson, Present at the Creation (Now York: W. W. Norton \& Company, 1969), p. 375. 


\section{The Role of the Troops}

Taft had also argued that even if a Sorlet attack came, 81x American divisions would never be capable of stopping 1t. Taft's view in this instanco seems sensible. Even with additional divisions supplied by the various nations of Western Europe, it is still difficult to understand how a massive Soviet invasion could have been contained. In answer to this polnt Administration supporters, such as General Luclus Clay, sought to assure the Senate that an Amerlcan force, even such a small one, would be so skilled and tenaclous that it would be capable of sustalning "the rather slow moving Russian attack" until adaltional allied forces could be brought to bear. 2 In light of the American mil1tary's less than brilliant record against a far less soph18ticated opponent in Korea, Clay's statement seems particularly absura.

A more plaustble explanation for the sending of troops hinged on a political motive. At least one columnist sar the long-term 1mplications of the issue at the time:

In the most. literal sense they [the six divisions] are the vanguard of a potential army that might never have come into existence if they were not there. As a military force they are not b1g enough to win a land war, but as a political force, the nuclous of larger armies, the generator of confldence and the will to resist, they could be a potent factor in

2The New York Times, Maroh 1, 1951, p. 16. 
daving the peace. 3

Simllarly, another observer noted, perhaps more succinctly, that America's role in providing troops to NATO was, in effect, "a deterrent commltment based on the bellef that if American intentions to prevent the upset of the European balance of power were made olear in advance, the likelihood of a challenge to that balance would be greatly reduced. 4

More recently, other witers, inclualng some from the so-called "revisionist" school of history, have come up with a related motive for the Administration's actions. This group is of the opinion that American troops were primarily sent to Europe to serve as "hostages" in order to insure all-out American participation in case of any milltary conflict. Speciflcally, the reasoning of this group 1s just the opposite of what General Clay's had been: small numbers of American troops would never be able to withstand any massive Sov1et attack, nor were they meant to: Their rolo was to act as a "tripwire" whose purpose would be to guarantee the full might of the American military would come orashing down on any force which attempted to rout them from the continent. Ultimately, of course, this meant that "any Soviet attack upon a NATO command containing Amerlcan troops

3 Anne O'Hare McCormick, "The Political Mission of Those Six Divisions," The New York Times, Febmaary 17, 1951, p. 14.

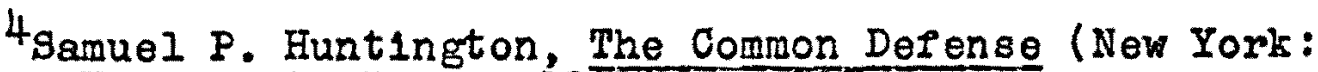
Columbia University Press, 196I), p. 313. 
would automatically trip a nuclear attack from the United States.:5

In other words, the loss of a sizeable number of American soldiers, coupled wh the realization that adoquate numbers or additional troops could not be despatched fast onough from the United States to hold the continent, would probably be reason, as one observer put 1t, to "create the casus bell1 atom101, at which point the strateg10 Alr Command would take over and unleash an atomic attack." 6

This theory seems credible, especielly since at least one high-level member of the Truman Administration has been unable or unwlling to respond to $1 t^{7}$ What emerges from all of this, however, is the curlous irony that 15 the logio of the revisionists is acoepted, then in the end the Admin1atrati on was relying on the capability of the Amerioan A1r Force to deliver a devastating nuclear attack on the Soviet Union, the atrategy Taft had advanced all along. Taft wented the United States to be prepared to carry out this

SWalter LaFeber, America, Rusa1a, and the Cold War, 1945-1966 (New York: John W1ley and Sons, Inc., 1967), p. 123 !

6Raymond Aron, The Great Debate (New York: Doubleday \& Company, Inc., 1965T, D. 23.

7 When asked about the revisionist theory by the author, Secretary Aoheson referred him to several chapters in his new book, Present at the Creation. AlI proved to be useful, but none, unfortunately, dealt with the revisionist "tripwire" explanation. Nor could the author find evidence of a respones to the theory by any other Administration defender. 
action without sacriflolng ground personnel in the process. The Administration, on the other hand, apparently felt that such an attack would never recolve the pol1tical and public assent necessary whin the Undted states unless American troops had already been k1lled by a sovlet aggressor force. Both atrategies assumed Amerlcan alr power would have the capability to carry out such a miesion. Fortunately, the alr force was never asked to prove this contention.

\section{The Exeout1ve and the Senate}

In questioning the President'g right to send troops anywhere without the approval of the senate, Taft and his oupporters were employing a tact10 that was anything but new. He was merely stirring up embers which periodically throughout American history have 1gneted over the constitutional question of the right of the executive branch to take m111tary action without the approval of the leglalative branch. Truman, already annoyed with Taft and company over a varlety of 18sues, saw Ilttle need to subm1t the troop question for their approval. The President mado his position clear in a press conference in January, 1951:

Q. Mr. President, maybe 1t's my "tin" ear, but I didn't get this stralght yet. In this particular case, with the debate raging in Congress over whether you do or do not have the authorlty to sena troops to Europe--and $\mathrm{Mr}$. Hoover sald not another man or another dollar should be sent--the debate has been quite general. Do I understand that you wiIl ask Congress for perm1ssion--

THE PRESIDENT. No.

Q. --before sending troops-- 
THE PRESIDENT. No, you do not want to take that Diew of the thing. I sald that--in case of necessity and it became necessary, for the defense of the Atlant10 Treaty countries, the Congress would be conaulted before troops were sent. I don't asis their permission, I just consult them [empheris

Truman went on to note in the same nows conference that If Senators Taft and Wherry, or anyone else, wanted to discuss this matter with him "the front door of the white House [was] always open." A public invitation of this sort was not what Taft had in mind. He desired a privete invitation whereby he and the President would arrive at some mutual arrangement in regard to the troops question. In fact, the whole notion that it was Truman's duty to gain the consent of Congress really meant the consent of the GOP leadersh1p.9 As 1t was, Truman sald nothing of his plans conoerning the troop lssue to the Republican leadership until after a declsion had already been made and commun1cated to the other NATO members. Truman's action were a olear Indication the harmonious days when the President and Senator Arthur Vandenburg worked out a blpartisen forelgn policy were nothing more than fond memorles. It seemed olear, as one observer has notsd, that "the procedures and

8U. S., President, "The President's News Conference of January II, 1951 " Public Papers of the Presidents of the United States: Hariy $\mathrm{S}$. Truman Weshington: United States

9coc1l V. Crabb, B1part1 san Forelgn Pollcy: Myth or Real1ty? (Evanston: Row, Peterson and Company, 1957), p. 94 . 
techn1ques designed to promote two-party cooperation in Iorelgn affalrs had falien into almost complete disuse, and nelther the Administration nor Republican leaders showed any evident desire to restore them." 10

The reaction in the Senate to the President's pollcy was mixed, even in his own party. Senator J. William Fulbright was firmly in his corner:

The Congress has the right and power to ralse the Armed Forces, but the President has the respons1b1lity for the command of those forces. If in the exercise of h1s best judgment the defense of this country requires the sending of troops to Europe, he has the power and the duty to do so. Congress, of course, can refuse to appropriate the money for the troops but that is a deolsion for which Congrese must take the responsibility. In the long run deolsions on military strategy are best lert to the Executive. II

Senator Paul Douglas, normally an Administration backer, was not so sure. He felt uneasy over the troop 1ssue because Secretary Achoson had stated before a congressional committee in 1949 that American troops would never bo sent to Europe under the NATO pact. Now 1 t was obvious troops were going to be sent and apparently without congressional Banction. Consequently, Douglas felt:

1t would not be proper, in my judgment, for the adminlatration now to try to put the agreement 1nto effect by purely Executive action upon the narrow grounds of 1 ts constitutional powers. For to do so would violate the explicit pleage given by

\section{Ib1d.}

IIU. S., Congressional Record, $83 d$ Cong., lst Sess., xovII, Part i; 520-521. 
the Secretary to the Senate when we had the power of refusing to ratify the treaty under which the Brugsels agreement was later negotiated. It would bo the patb of honor instead for the administration to submit the question of approving the Brussels agreement to at least the Senate and possibly the

In the end Truman chose a compromise, but one whlch was favorable to his position. With the Administration's approval the issue was allowed to be alred in the joint hearings of the Armed Forces and Forelgn Relatione Committees. Since both committees were made up of men largely favorable to the Administration's position, this action almost insured a pro-Administration outcome, thereby neatly outmanouvering Taft. The mowe also had the additional advantage of pacifying dissident Democrats, such as Dougles, who now felt the Senate had been properly consulted.

Taft's allegation that the Senate had not been given Its const1tutional due was further weakened when many prom1nent Republicans, convinced by the hearings, finally poted for Resolution 99. Th1s avolded a showdown struggle in tho Senate which probably would have resulted in a bitter part1 san wrangle of considerable duration: But because of Truman's apt handling of the 1ssue and because of the supposed Soviet threat to Westerin Europe, many "Republioan senators did not dare to wisk the consequences of defeating the treaty."13 Some of them were probably fearful of 12 Ibta., p. 230. 13Malcolm E. Jowell, Senator1al Politlos and Fore1gn Polioy (n.p., University of Kentucky Press, 1962), p. 38 . 
falling victim to a "soft on communism" charge at some later date if they refused to support a milltary alliance againgt it at this time.

\section{Aftererfeots}

The long term implications of the great dobate for both internal American polltios and foreign affairs are admittediy difficult to sumised. On the surfaco, as has already been shown, the Administration ras victorious. It succeeded in 1 ts desire to move additional troops to Europe, a move whlch turned out to be a thin entering wedge in light of the numbers of American troops which were to follow over the years.

A broader examination, however, suggests the debate, along with those issues which leds up to and followed it, proved to be disastrous to the Democratic Party. For although some conservative Republicans were earnestly seekIng a change in America's defense posture, it seems clear that in a larger sense they saw the great debate as yet another opportunity to make political hay for the 1952 elect1ons. Every time the Administration was discredited, the Republican Party was assured of additlonal votes. One careful student of the period, historian Ronald J. Carlai, has frankly concluded this' was the major motivation of the Republican dissidents. Commenting on the perty's attitude toward Korea in particular, Caridi remarked: 
They first supported the American 1ntervention, then retreated from the implications of that support; they steadratly called for American withdrawal. . then passionately associated themselves With the "no substitute for victory" philosophy of MacArthur. Finaliy.. the perty nominated for the Fresidenoy a military hero whose platform lacked any concrete program for peace even ag it disavowed both unification and an all-out victory. Crit101sm by the Republican party during the Korean War was Justiflable; but when the nature of a party's dissent indicates that its members are motivated more by political expediency than by a desire to present $a$ consistent and viable alternative to Adqinistration policies, then cengure is in order. 14

Censure may have been in order, but when it came the American public, via the ballot box, directed it against the Democrats. The Republican Party's election viotories of 1952 indicated that its strategy had been successful. It may, in fect, have been too successful. As one foreign observer has noted: "Not only did 1t do untold electoral damage to the Democratic Party but it Iaid the basis Ior a signifloant change in American [fore1gn] pol1cy."15 Dean Acheson, writing in his memolrs, admits the period was a 'polsonous one and 1t "had a highly toxic effect on the American public." St1ll, he found that the "Ioss of conf1dence at home and abroad in the conduct of our forelgn afrairs was not the proximate cause of any change in our forelgn pollcy, but it added to our diffloulties and by so

14Ronald J. Car1d1, The Korean War and Amer1can Pol1EIes: The Republican Party as a Case Study (Ph1ladolphia: University of Pennsylvan1a Press, 1968), p. 175.

15 The Times (Lonaon), September 6, 1954, p. 7 . 
do1ng diminished our effectiveness."16

Perhaps there was no noticeable change in the direction of forelgn policy during the remaining year and a half of the Truman Administration, but a subtle change was occurring. A whole set of attitudes conoerned with the menace of Communism in Asla began to permeate the upper echelons of government. Korea, of course, started 1t, but the attacks and campaigns of Taft, Hoover, Knowland, and thelr followers must share a good deal of the responsiblilty for that change. Largely because of the momentun of their propaganda, American foreign policy became reoriented, with a greater emphasis placed upon the importance of Asia. Once the war In Korea was terminated with a state of permanent truce, the United States did not remove 1 ts presence from As1a; it increased 1t: fifty thousand troops remained in Korea; Chlang Ka1-shek continued to recelve vast amounts of m1litary and economio atd; the French were first alded and eventually replaced in a hopeless at tempt to suppress "Communist subversion" in Southesst Asia; and the SEATO alliance eystem was established, in an effort to do for the entire region what NATO had axposedly done for Western Europe. In short, the whole concept of combating Communism by containment, which had originally been designed for events in Europe, was also adopted for Asia under the direotion of the $=$ $16_{\text {Aoheson, p. } 528 .}$ 
Elsenhower Administretion. Later Democratic regimes not only adcepted all of this as worthwhile but sought to expand America's role there as well. No thought was apparently given to the possiblilty that by so do1ng the United States might seriously overextend itsolf.

In essence, then, wost of the argumentis in regard to Asla advanced by Taft and his troupe were accepted and eventually put into practice by later administrations. (Even the much touted superiority of alr power was given another chance in Vietnam-where it met with only marginal sućcese.) The 1rony of the great debate was that while Taft and his supporters lost the battle in 1951 over the troopsto-Europe 1ssue, they in effect won the war: Asla was to be champloned as never before, perhaps beyond anything Taft had Imagined possible. Aside from the troop 1ssue, the only concept advanced by Taft and Hoover during the great debate that was not later acknowledged as gospel was the propos1tion that excessive defenso spending would become selfdestructive. Yet this may well have been their most signif1 cant prediction. 


\section{A SELECTED BIBLIOGRAPHY}

\section{Books}

Acheson, Dean. Power and D1plomacy. Cambridge, 1958. - Present at the Creation. New York, 1969. Adler, Sel1g. The I solationist Impulse. New York, 1957. Aron, Raymond. The Great Debate. Garden City, 1965.

Batley, Thoma A. A Diplomatic H1story of the American People. New York, 1964.

Ball, George W. The D1sc1pline of Power. Boston, 1968. Brown, Seyon. The Faoes of Power. New Yorts, 1968.

Caria1; Ronald J. The Korean War and Amerloan Polit1cs: The Republican Party as a Case Study. Philadelphia,

Crabb, Cec1l V., Jr. B1partisan Fore1gn Polloy: Myth or Real1ty? Evanston, 1957 .

Fleming, D. F. The Cold War and Its Origins. Vol. II. Garden C1ty, 1961.

Goldman, Eric F. The Cruclal Decade--and After. New York, 1960.

Graebner, Noman A. The New Isolation1 sm. Now York, 1956.

H1ggins, Trumbull. Eorea and the Fall of MacArthur. New York, 1960:

Huntingt on, Samuel P. The Common Defense. New York, 1961. I may, Lord. NATO, The First Five Years, 1949-54. The

Israel, Fred L. (ed.). The State of the Union Messages of the Presidents. VoI. III. New York, 1966.

Jeweli, Maloolm E. Senatorial Polltios and Forelgn Poller. n.p., 1962. 
Knorr, Kluss (ed.). NATO and American Security. Princeton,
1959.

LaFeber, Walter. America, Russ1a, and the Cola War. Ner York, 1967.

Lathem, Earl. The Communist Controversy in Washington. Cambridge, 1966 .

Latourette, Kenneth Scott. The American Record in the Far East, 1945-51. New York, 1953 . Lukacs, J. A. A History of the Cold War. Garden City,
ig 6 .

Osgood, Robert E. Alliances end American Forelgn Pollcy. Balt 1more, 1968 .

Ph1lips, Cabell. The Truman Fresiaenoy. New York, 1966.

Stebbins, Richard P., and the Counc1l on Forelgn Relations. The United States in World Afrairs 1251. New York, 1952 .

Stoel, Ronald. The End of Alliance: America and the Future of Europe. New York, 1964.

- Pax Amer1cana. New Yorix, 1967.

Spaniex, John W. The Truman-Macarthur Controversy and the Korean War. Cambridge, 1959.

Taft, Robert A. A Forelgn Pollcy for Amerlcans. Garden City, 1951.

Truman, Harry s. Memo1rs. Vol. II. Garden City, 1956. Tsou, Tang. America's Failure in China. Ch1cago, 1963.

Van Der Beugel, Ernst H. From Marshall Ald to Atlant10 Partnership. Amsterdam, 1966.

Vandenberg, Arthur H., Jr. The Private Papers of Senator Vandenberg. Boston, 2952 .

Warne, J. D. NATO and 1ts Prospects. New York, 1954.

White, Theodore H. Fire in the Ashes. New York, 1953.

White, W11.11am S. The Tart Story. New York, 1954. 


\section{Articles and Periodicals}

Bymes, James F. "Firm Stand by a United People May Prevent War," Vital Speeches, February 15, 1951, pp. 268-270.

"The Congress and U. S. Forelgn Relations," Congresglonal Digest, XXX (February, 1951), 35-39!'

"Debate Goes On," Newsweek, Febmiary 19, 1951, p. 20.

Deway, Thomas A. "Enlarge North Atlant1c Treaty," V1tal Speeches, March 1, 1951, pp. 290-293.

"The Execut1ve Power Today," Congressional Digest, XXX (Fobruary, 1951), 4I, 64.

"Fore1gn Polloy: What-to-do Debate," Newsweek, January 1, 1951, pp. 10-12.

"Fundamental Republican," Time, December 10, 1951, pp. 27-28.

"Great Debate," Newsweek, January 22, 1951, pp. 18-19.

"Great Debate Finale," Newsweek, April 16, 1951, pp. 27-28.

Hoover, Herbert. "Our National Policies in this Crisis," Vital Speeches, January 1, 1951, pp. 165-167.

"We Should Revige Our Foreign Policies," Vital Speeches, February 15, 1951, pp. 262-265.

"Hoover IIne Grows," The New Repub11c, January 15, 1951, p. 7. Judd, Walter. "How Can'We Be So Stupidg" V1tal Speeches, Maroh 1, 1951, pp. 293-300.

Knowland, Wllliam F. "A Fateful Hour: Necessity for Combatting Aggressive Communism in Asla," V1tal Speeches, December 15, 1950, pp. 154-158.

"Kor 80 and World Pol1tios," The New Republic, April 16, 1951, = pp. 5-6.

"The 'Lame Duck' Session Features Anxiety and Taxes," Congressional_D1gest, XXX (January, 1951), 1-2.

Moley, Raymond. "The Hoover Challenge," Newsweek, January 1, 1951, p. 60 .

The New York Times. December, 1950-May, 1951. 

Rovere, Richard H. "What's Happened to Tart?" Harper'B,
CCIV (Apr1I, 1952), 38-44.

Schleainger, Arthur M. Jr. "The New I solationi am," Atlant1c, CLXXXIX (May, 1952), 34-48.

Stevionson, Adla1 E. "There Are No Gibraltara," V1tal Speeches, February 15, 1951, pp. 284-288.

Tart, Robert A. "The Xorean War and MacArthur's D1smissal," V1tal Speoches, May 1, 1951, pp. 420-422.

The Times (London). January, 1951-May, 1951.

"Troop Compromise," The New Republ1c, April 16, 1951, p. 8. Wertenbaker, Charles. "The Chine Lobby," The Reporter, Apr11 15, 1952, pp. 4-24.

\section{Government Publioations}

The Department of State Bulletin. December, I950-May, 1951.

Publ1c Papers of the Presidents of the Un1ted States: Harry S. Truman. Washington, 1965.

U. S. Congressional Record. September, 1950; December, 1950May, 1951.

U. S. Senate. Committee on Forelgn Relations. Hearings on the North Atlantic Treaty. 8lst Cong., lst Sess.,

Washington, 1949.

- Jolnt Senate Committee on Arned Services and Forelgn Relations. Hearings on the Military S1tuation in the Fas East. 82a Cong., lot Sess., Washington, 1951. 


\section{APPENDIX}

\section{SENATE RESOLUTION 99 AS AMENDED}

\section{Resolved That--}

1. the Senate approved the action of the President of the United States in cooperating in the common defenelve effort of the North Atlantio Treaty nations by designating, at their' unanimous request, General of the Army Dwight $D$. Elsenhower à Supreme Allied Commander, Europe, and in plasIng Armed Forces of the United States in Europe under his command;

2. It 18 the belief of the Senate that the threat to the security of the Unfted States and our North Atlant10 Treaty partners makes 1t necessary for the Undted States to station abroad such units of our Armed Forces as may be necossary and appropriate to contribute our fa1r share of the forces needed for the jolnt derense of the North Atzantio area;

3. It 1s the sense of the Senate that the Prosident of the United States as Commander in Chief of the Armed Forces, before taking action to send units of ground troops to Europe under article 3 of the North Atlantic Treaty, should consult the Secretary of Defense and the Joint Chlers of Staff, the Committee on Forelgn Relations of the Senate, the Committe on Forelgn Affairs of the House or Representatives, and the Arned Services Committees of the Senate and 
the House of Representatives, and that he should likewlse consult the Supreme Allied Commander, Europe;

4. It is the sense of the Senate that before sending uniti of ground troops to Europe under article 3 of the North Atlantic Ireaty, the Joint Chlofs of Staff ghall certify to the Secretary of Defense that in thelr oplnion the parties to the North Atlantic Treaty are giving, and have agreed to give full, reallatic force and effect to the requirement of artiole 3 of sald treaty that "oy means of continuous and effective selfhelp and mutual a1d" they w1ll "maintain and develop, thoir individual and collective capaolty to resist armed attack," especially insorar as the creation of combat units is concerned;

5. the Senate herewith approves the understanding that the major contribution to the ground forces under General Elsenhower's command should be made by the European members of the North Atlantic Treaty, and that such units of United States ground forces as may be assigned to the above command shall be assigned on is after the Joint Chiefs of Staff certify to the Secrotary of Defense that in thelr opinion such assignment is a necessary step in strengthening the security of the United States; and the certified opinlons referred to in paragraphs 4 and 5 shall be transm1t ted. by the Secretary of Defense to the President of the United States, and to the Senate Committees on Forelgn Relations and Armed Services, and to the House Committee on Forelgn 
Affalrs and Armed Services as soon as they are recelved;

6. It is the sense of the Senate that, in the interests of sound constitutional processes, and of national unity and understanding, congressional approval should bo obtained of any pollcy requiring the assignment of American troops abroad when such assignment is in 1 mplementation of article 3 of the North Atlant10 Treaty; and the Senate hereby approves the present plans of the Pregldent and the Jo1nt Chlefs of Staff to send four adaltional alvisions of ground foroes to Western Europe, but it 18 the sense of the Senate that no ground troops in adaltion to such four divisions should be sent to Western Europe in 1mplementation of article 3 of the North Atlantic Treaty whout further congressional approval;

7. It is the sense of the Senate that the President should submit to the Congress at intervals of not more than 6 monthe reports on the implementation of the North stlantio Treaty, including such information as may be made avallable for tinls purpose by the Suprene Allied Commander, Europe:

8. It 18 the sense of the Senate that the United States should seek to ellminate all provisions of the exist1ng treaty w1th Italy which impase I1mitations upon the military strength of Italy and prevent the performance by Italy of her obligations under the North Atlantic Treaty to contribute to the rull extent of her capacity to the derense of Western Europe; 
9. It 1s the sense of the Senate that consideration should be given to the revision ofplans for the defense of Europe as soon as possible so as to provide for utilization on a voluntary basis or the military and other resources of Western Germany and Spain, but not exclusive of the military. and other resources of other nations. 